\title{
The Politics of World Polity Script-writing in International Organizations
}

\author{
Kentikelenis, Alexander E.; Seabrooke, Leonard
}

Document Version

Accepted author manuscript

Published in:

American Sociological Review

DOI:

$10.1177 / 0003122417728241$

Publication date:

2017

License

Unspecified

Citation for published version (APA):

Kentikelenis, A. E., \& Seabrooke, L. (2017). The Politics of World Polity: Script-writing in International

Organizations. American Sociological Review, 82(5), 1065-1092. https://doi.org/10.1177/0003122417728241

Link to publication in CBS Research Portal

\section{General rights}

Copyright and moral rights for the publications made accessible in the public portal are retained by the authors and/or other copyright owners and it is a condition of accessing publications that users recognise and abide by the legal requirements associated with these rights.

Take down policy

If you believe that this document breaches copyright please contact us (research.lib@cbs.dk) providing details, and we will remove access to the work immediately and investigate your claim. 


\title{
The Politics of World Polity: Script-writing in International Organizations
}

\section{Alexander E. Kentikelenis and Leonard Seabrooke}

Journal article (Accepted manuscript)

\begin{abstract}
CITE: Kentikelenis, A. E., \& Seabrooke, L. (2017). The Politics of World Polity: Script-writing in International Organizations. American Sociological Review, 82(5), 1065-1092. DOI: 10.1177/0003122417728241
\end{abstract}

Copyright [C American Sociological Association 2017. Reprinted by permission of SAGE Publications.

DOI: https://doi.org/10.1177/0003122417728241

Uploaded to Research@CBS: December २०18 
Alexander E. Kentikelenis

University of Oxford

Leonard Seabrooke

Copenhagen Business School

\title{
The Politics of World Polity: Script-writing in International Organizations
}

\begin{abstract}
Sociologists have long examined how states, intergovernmental organizations (IGOs), international nongovernmental organizations (INGOs), and professional groups interact in order to institutionalize their preferred norms at the transnational level. Yet, explanations of global norm-making that emphasize inter-organizational negotiations do not adequately explain the intraorganizational script-writing - that is, the codification of norms in prescriptive behavioral templates - that underpins this process. This article opens the black box of how scripts emerge and institutionalize within IGOs. Script-writing is a function of both world-cultural frames and material interests, held by different intra-organizational actors: scientific IGO staff and state representatives in governing bodies, respectively. The interplay between these frames and interests determines whether scripts will institutionalize. In this theoretical model, worldcultural and power-political explanations are pertinent to different, mutually informing, and coexisting aspects of the script-writing process. As a corollary of our approach, we present a conceptual framework for the study of intra-IGO script-writing, which is contingent on three normative struggles: among IGO staff, within an IGO's board of directors, and between the staff and the board. To empirically substantiate our arguments, we examine scripts on taxation and capital controls by the International Monetary Fund. We conclude by discussing the broader implications of our model for the study of international organizations and the engines of global norm-making.
\end{abstract}

\section{Keywords}

global governance, global norms, policy scripts, international organizations, International Monetary Fund, taxation, capital controls

\section{How to cite}

Kentikelenis, Alexander E, and Leonard Seabrooke. 2017. "The Politics of World Polity: Script-Writing in International Organizations." American Sociological Review 82(5): 1065-92. 
Sociologists have long devoted attention to how norms emerge and institutionalize at the international level (Babb 2007, 2009, 2013; Babb and Chorev 2016; Boli and Thomas 1997, 1999; Chorev 2012a, 2012b, 2012c; Drori, Meyer, and Hwang 2006; Halliday 2009; Halliday and Carruthers 2007, 2009; Hironaka 2014; Meyer, Frank, et al. 1997; Schofer 2003, 2004; Schofer et al. 2012). The predominant view is that global norm-making entails an iterative process involving states, intergovernmental organizations (IGOs), international nongovernmental organizations (INGOs), and professional groups (Halliday and Carruthers 2007, 2009). These actors interact and compete to yield "dominant policy scripts" that are then taken up by countries around the world in some locally specific form (Boyle, Kim, and Longhofer 2015; Chabot and Duyvendak 2002; Chorev 2012a; Levitt and Merry 2009). Yet, despite highly nuanced studies of inter-organizational norm-making, less light has been cast on intraorganizational processes of script-writing that codify norms in prescriptive behavioral templates. After all, before an actor (e.g., a state or an IGO) engages with others to institutionalize their preferred script, that actor needs to decide which script is desirable.

In this article, we open the black box of script-writing within IGOs, who are central agents in the emergence and institutionalization of global norms. How are scripts produced and by whom? To examine these issues, we draw on two sociological traditions. First, building on insights from the World Polity school, we approach IGOs as carriers of ideas and models that reside within them due to their mandate and culture, and that emanate from scientific principles (Boli and Thomas 1997, 1999; Drori and Meyer 2006a, 2006b; Meyer, Boli, et al. 1997; Meyer, Drori, and Hwang 2006; Meyer, Frank, et al. 1997). Second, following economic sociology and political economy research, we understand these organizations as sites of political contention (Babb 2009; Babb and Chorev 2016; Chase-Dunn 1998; Chorev 2012b, 2012c, 2013; Halliday and Carruthers 2007, 2009; Wade 1996, 2011).

These approaches are often viewed as incompatible, but scope for convergence exists. We identify script-writing within IGOs as a function of world-cultural frames and material interests, each held by different intra-organizational actors: bureaucrats and state representatives, respectively. The interaction between these frames and interests determines how scripts are produced and institutionalized to underpin and propagate a given norm. In this theoretical model, world-cultural and power-political explanations are pertinent to different, mutually informing, and coexisting aspects of the script-writing process. As a corollary of our 
approach, we also present a conceptual framework for the study of script-writing within international organizations.

To empirically scrutinize our argument, we focus on script-writing related to two norms that are central to the functioning of late capitalism. The first is the norm that tax burdens should fall on a broad consumer base rather than on trade or corporate and personal income. The second is the norm of free movement of capital, which has shaped contemporary economic globalization. Together, they permit high capital mobility for financial interests, while states support themselves via the consumption of their masses. Within these broader norms over consumption-based taxation and capital openness, we examine attempts at the institutionalization of policy scripts related to two issues: the value-added tax (VAT), which applies at different stages of domestic production and sale of goods (e.g., from the seller of raw material to a manufacturer, from the manufacturer to a retailer, and from the retailer to the final customer); and capital account liberalization - that is, measures to promote the free movement of capital without regulatory costs and restrictions.

The focal IGO tasked with developing scripts over VAT and capital account liberalization is the International Monetary Fund (IMF). The IMF is a key actor in defining "appropriate" economic policy and is among the "world's most powerful agents of economic reform" (Halliday and Carruthers 2007:1137). In both cases, IMF staff developed detailed scripts. The success or failure of script institutionalization ultimately depended on three normative struggles: within the bureaucracy over the appropriate scientific basis for policy; within the IMF's board of directors, where its political masters are represented; and between the staff and the board. The tax-related script became institutionalized due to normative consensus. In contrast, due to normative contention, the staff's preferred script on capital account liberalization failed to institutionalize. Even though this script was favored by a powerful combination of high-income countries and IMF staff, its institutionalization was blocked by the concerted efforts of weaker actors: developing countries. Power asymmetries are crucially important in global norm-making, but they do not play out in institutional vacuums: existing rules can be leveraged by coalitions of seemingly weak actors to block script institutionalization.

As World Polity literature explains, international organizations are agents of norm diffusion that represent "the organizational embodiment of world society" (Hironaka 2014:81). In this context, our account documents the tensions between 
science and politics in script-writing within international organizations: competition between, or reconciliation of, staff-driven scientific worldviews and political positions within governing boards determine script content. These conflicts reveal actors' theorization processes about how best to advance toward supposedly universal normative goals, and their attempts to define the terms of this rationalization, including who benefits more from its distributional implications. Both scientific and political actors follow a conception of selfinterest that nevertheless affirms world-cultural forces (Kim and Sharman 2014; Meyer, Boli, et al. 1997:157). These scientific and political tensions manifest across a range of IGOs, INGOs, and other organizations with a focal role in global norm-making. In short, uncovering the dynamics of intra-organizational script-writing reveals the politics of World Polity.

\section{THE EMERGENCE AND INSTITUTIONALIZATION OF NORMS AT THE GLOBAL LEVEL: A SYNCRETIC APPROACH}

Global norm-making refers to the emergence and institutionalization of norms"behavioral prescriptions that are accepted by subjects as legitimate and authoritative" (Halliday 2009:268) - at the transnational level. This process is recursive, entailing rounds of interactions among global actors (including states, IGOs, INGOs, and epistemic communities), within national actors, and between global and national actors (Halliday and Carruthers 2007, 2009; Chorev 2012a). Multiple and prolonged debates and negotiations between these actors produce and fine-tune the dominant norms of contemporary globalization. In turn, norms are regularly codified in the form of a script, which serves as "a medium by which [an organization] frames its own definition of a reform issue: a diagnosis of problems followed by a set of prescriptions" (Halliday, Block-Lieb, and Carruthers 2010:84). ${ }^{1}$ Multiple scripts can circulate at the transnational level, championed by different actors, and they are recursively adapted, institutionalized, or discarded.

Despite its heuristic merits, the recursivity framework has not devoted adequate attention to the crucial question of how scripts are developed within the actorscommonly, organizations - that promote them. We identify this process as intraorganizational script-writing: each organization develops a distinct script on appropriate policy over an issue, and the script is subsequently taken forward to norm-making at the global level, where it competes with alternative scripts by other actors (see Halliday and Carruthers 2007, 2009; Halliday et al. 2010). In our account, recursivity is still present and operates through intra-IGO processes. 
In other words, national actors and politics not only influence interorganizational global norm-making, but they are also present within the microcosms of the organizations involved. The dynamics of such intraorganizational script-writing are especially important to understand when a particular organization clearly dominates the shaping of global norms (Jupille, Mattli, and Snidal 2013). This article focuses on such a case.

We draw on two sociological traditions that offer distinct explanations of the actors - and their resources and strategies - involved in script-writing. World Polity scholars in organizational sociology explain that specific "scientized" scripts and ideas reside within IGOs and INGOs as a function of their mandate and culture (Boli and Thomas 1997, 1999; Drori and Meyer 2006a, 2006b; Hironaka 2014; Meyer, Boli, et al. 1997; Meyer, Frank, et al. 1997). According to this line of argument, the output of international organizations-including scripts - aims to "disciplin[e] and rationaliz[e] the chaotic uncertainties of social environments, facilitating the creation of articulate rule systems" (Drori and Meyer 2006b:31). Their claim to scientific authority emanates from knowledge and expertise possessed by their bureaucracies due to formal training, career background, and socialization. For example, Meyer, Frank, and colleagues (1997) examine how the world environmental agenda was promoted by international organizations, particularly those of the UN system, using scientific evidence to shape policy. While IGOs are considered central to norm propagation, World Polity accounts do not devote considerable attention to script-writing by intraorganizational actors, who are generally understood as enactors of world-cultural frames "rather more than they are self-directed actors" (Meyer, Boli, et al. 1997:150). That is, the extra-organizational environment shapes world culture, which is subsequently diffused around the world by technocrats using scientized scripts.

In contrast, economic sociology and political economy scholarship emphasizes contentious aspects of global norm-making (Babb 2009; Babb and Chorev 2016; Chase-Dunn 1998; Chorev 2012b, 2012c, 2013; Halliday and Carruthers 2007, 2009). Rather than a projection of world culture, the production of scripts reflects fundamentally political processes, the outcome of which depends on the differential resources of the actors involved. Contentious struggles involve economic, political, ideational, and social resources, which are used strategically during script-writing. For example, Babb (2009:141-43) explains how the U.S. Treasury "tamed" the Inter-American Development Bank in the 1980s, when it chose to disregard the U.S. script over appropriate "growth-oriented policy 
reforms." In these accounts, IGOs serve as battlegrounds for different normative preferences; they are terrains where actors coalesce and compete over which norms will become institutionalized. The power asymmetries inherent in globalization manifest in these efforts to yield scripts (Halliday and Carruthers 2009).

World Polity scholars may retort that detailing the haggling over scripts is largely irrelevant, as agents are operating within a norm-conforming rationality. For example, knowing the political dynamics in each nation-state is not necessary for understanding the importance of IGOs for state formation in the post-war system ( $\mathrm{Li}$ and Hicks 2016). Yet, other scholars would rebut that the World Polity approach operates at far too grand a level of aggregation, and that action is not global but context- and location-bound, centering on contestation (Wimmer and Feinstein 2010, 2016).

We hold that the theoretical tools of World Polity and contention accounts can be fruitfully integrated to open up the black box of intra-IGO script-writing. Enabling this syncretic approach is the fact that two types of actorhood coexist within IGOs (Chorev 2012b, 2012c, 2013). ${ }^{2}$ First, scientific staff serve as conduits for norms circulating in world culture and are thus tied to forms of rationality and theorizing. Second, IGOs' authority is delegated from states, which can have political interests in status quo sustenance or normative change (Meyer 2000). Struggles between science and politics in IGOs manifest in the interactions between these types of actors, and their outcomes depend on differing power resources, policy preferences, and opportunity structures.

\section{SCRIPT-WRITING IN INTERGOVERNMENTAL ORGANIZATIONS: A CONCEPTUAL FRAMEWORK}

We approach script-writing within IGOs in two analytical steps that enable finegrained modeling of intra-organizational dynamics. First, we understand scriptwriting as contingent on interactions between organizational staff and memberstates operating through their representatives to these organizations (Babb 2009; Chorev 2012b, 2012c; Halliday, Pacewicz, and Block-Lieb 2013; Wade 1996). The former are carriers of scientific knowledge and expertise, as outlined in World Polity literature (e.g., Drori and Meyer 2006a, 2006b). The latter have created oversight structures - often called executive boards, governing councils, or boards of directors - that have ultimate authority over decision-making, including action or inaction over legitimating or challenging norms (Koremenos, Lipson, and 
Snidal 2001; Martinez-Diaz 2009; Meyer 2000). As summarized in Table 1, we anticipate four possibilities in these interactions, dependent on the type of policy activity by staff (consistent or mixed) and the degree of attention by the board. By policy activity, we mean concrete actions by staff, rather than the ideas some or all staff may hold; that is, knowledge and expertise must be manifest in policy design and output, as it is conceivable that IGO staff may not be able to put their ideas about appropriate policy into practice.

\section{[Table 1 here]}

Script stability and tight oversight (quadrant 1). When staff engage in consistent policy activity that attracts persistent attention by the board of directors, this reflects script stability and tight oversight of IGO actions. For instance, the practice of "conditionality" by international financial institutions - making the disbursement of loans conditional on implementing policy reforms - is a wellestablished script that affirms a global moral hazard-abatement norm, ${ }^{3}$ but nonetheless one under tight oversight by IGO boards that control its application (Babb and Carruthers 2008).

Consensus over scripts (quadrant 2). When staff engage in consistent policy activity but the IGO board has not devoted attention to these practices, this reflects consensus over scripts being enacted (i.e., we assume that boards will devote attention in cases of controversy). For example, in their discussion of the IMF, Halliday and Carruthers (2009) explain how staff decided on the "house view" regarding bankruptcy regimes, but they do not examine whether the IMF board endorsed or objected to such norm-making; they imply that the board's role was irrelevant in this instance.

Contention over scripts (quadrant 3). When staff engage in mixed or inconsistent policy activity (e.g., by trying to institutionalize new scripts) and the board devotes consistent attention to their actions, this suggests contentious scriptwriting. That is, there is no institutionalized course of action for how to address a given policy problem. This contentious process likely entails elements of political struggles and scientifically informed decision-making. For instance, when World Health Organization staff attempted, in line with scholarly advances, to shift the organization's focus to social determinants of health in the 1970s and 1980s, its powerful member-states - particularly the United States-blocked the institutionalization of relevant norms, as they contradicted the emerging neoliberal orthodoxy of the time (Chorev 2012b). 
No clear script preferences (quadrant 4). When staff engage in mixed policy activity and the board does not devote attention, we assume that no prevailing scripts have emerged and that ad hoc decisions are made that do not reflect deep commitment to a particular mode of action.

Caution is necessary in interpreting the meaning of inattention by a board, as it may be silent because staff are implementing its wishes. Consequently, we distinguish between two cases: When staff engage in consistent policy activity but the IGO board never devoted attention to the issue, then board inattention reflects staff autonomy (see quadrant 2 of Table 1 and the VAT case study below). Members of IGO governing boards are generally able to propose agenda topics; if they choose to contest a policy, they have ample opportunity to do so. In contrast, when staff engage in consistent policy activity after the board has devoted attention to institutionalizing a script, then board inattention reflects staff compliance to the board's will. No more explicit attention is required, unless the staff lapse in their duties and the board needs to correct them (quadrant 1 in Table 1). Both cases are instances of consensus, albeit the former denotes staff autonomy and the latter reflects staff compliance. Adjudicating between the two explanations requires historicized and contextualized analysis of script-writing.

The second step of our model adds a layer of complexity to factor in power asymmetries and how these manifest in intra-organizational script-writing. The interactions we have discussed thus far treat attention devoted to a given script as an indicator of consensus or contention. But this does not reveal power asymmetries in these interactions, which can take three forms: among staff, within the board, and between staff and the board.

As schematized in Figure 1, we understand the workings of IGOs as contingent on interactions between their board of directors and staff, with each structure having internal power hierarchies. For boards, power resources are determined by a range of factors, depending on the organizational governance structure: voting rights and procedures, differential contributions to the budget, coalition-building, informal conventions, and limits imposed by the mandate (Martinez-Diaz 2009). For staff, power resources are determined by hierarchical structures within the organization, hiring limits and procedures, and scientific regard (Woods 2006). In our model, board meetings serve as the key venue where staff and board members interact: staff members attend meetings to present policy proposals and defend their preferred approach. Within IGOs, boards not only mediate states' 
political interests, but they also have an important control function over staff behavior, casting a shadow over what kind of policy thinking is possible (Pauly 1997). Formal regulations, informal norms, and anecdotal evidence suggest that other interactions - beyond board meetings - between board members and staff over policy issues are rare and discouraged. The exception relates to heads of IGOs, who try to reconcile the preferences of staff and board members to build consensus.

\section{[Figure 1 here]}

In the study of script-writing in IGOs, considering board-staff interactions and power asymmetries within each structure is both feasible and necessary for providing nuanced explanations. As this framework implies, following Halliday (2009), overlap or mismatch between actor preferences affects the probability of script institutionalization: if the interests of those who are envisaged to adopt normative prescriptions are not satisfied, they will likely view these prescriptions as illegitimate. Our model allows us to zoom in on which scientific and political actors are included in, or excluded from, global norm-making processes, and to trace if and how their preferences feed into script-writing. The focus on power asymmetries in script-writing suggests why policy feedback from weaker actors may be blocked from entering recursive feedback loops, unless these actors utilize the institutional setting to their advantage (see our case study on capital controls below). Consequently, our model can explain structural dependencies between recipients of IGO scripts (commonly, states) and the power behind the generation

of those scripts. It can also explain why preferences of an IGO's board or staff change in response to external developments. This includes rises in the domestic political salience of a script that alter board dynamics (Quinn and Toyoda 2008; Walton and Ragin 1990), or the formation or collapse of scientific consensus that alters staff views on appropriate script content (Shwed and Bearman 2010). These external pressures become internal to an IGO when intra-organizational actors adjust their preferences and actions.

\section{RESEARCH DESIGN}

To study script-writing in IGOs, we focus on the workings of the IMF. It is a focal organization in developing scripts to transform economies (Jupille et al. 2013), and it does so through lending to countries in economic trouble, monitoring its members' economic policies, providing technical assistance, and acting as a venue for international economic policy coordination (Babb and 
Kentikelenis 2018). These activities are decisive for the long-run developmental trajectories of middle- and low-income countries, and they are crucial for the lived experience of economic change for the billions of people inhabiting countries that have turned to it for support (Chang 2006; Kentikelenis 2017a; 2017b; Kentikelenis, Stubbs, and King 2016). As a consequence of the policies it advocates in developing countries (where it has had the most impact), the IMF also influences investment opportunity structures for capital and industry in wealthy nations, thereby indirectly affecting high-income countries' political economies.

Our theoretical rationale for selecting this case follows King and Sznajder's (2006) neo-Lakatosian approach, offering a macro-causal analytic combined with thick and historicized description on the basis of new evidence. In this approach, cases are selected due to their "heightened importance in the intersubjective world of the community of scholars" and serve as "battleground[s] for comparing research traditions" (King and Sznajder 2006:767). Indeed, the IMF has attracted extensive sociological attention (e.g., Babb 2003, 2007; Broome and Seabrooke 2015; Chorev and Babb 2009; Dobbin, Simmons, and Garrett 2007; Halliday and Carruthers 2007, 2009) and is among the most analyzed IGOs in the fields of political science, economics, and history (see Ban and Gallagher 2015; Grabel 2011; Helleiner 2014; Vreeland 2007; Wade 2011).

We selected two instances of IMF script-writing: over VAT and capital controls. We examine the former as a case of scientized, consensus-based script emergence and institutionalization (quadrant 2 in Table 1), and the latter as a case of contentious script emergence and ultimately unsuccessful institutionalization (quadrant 3 in Table 1). Both cases concentrate on intra-organizational scriptwriting between the early 1980s and early 2000s. These periods were inductively selected to cover the cycle from script emergence to successful or failed institutionalization.

Before outlining our data sources, a brief note on decision-making and staffing at the IMF is pertinent. The organization's main decision-making body is its Executive Board (henceforth, Board), which meets three times per week to oversee IMF activities. The Board is composed of 24 Executive Directors (henceforth, Directors) who are appointed by member-states (known as "shareholders"), and who wield voting shares depending on the economic size of the countries they represent. Only eight countries with high voting shares appoint their own Director; the remaining IMF members form constituencies of 4 
to 24 countries, represented by a single Director. The allocation of votes privileges high-income countries, and it remained broadly unaltered over the period covered in this article (see Table A1 in the Appendix). For example, the United States has held between 17 and 20 percent of the total votes, whereas the Francophone sub-Saharan African constituency-representing more than 20 countries - has held only about 2 percent of the votes.

Yet, the importance of voting shares should not be overemphasized: votes almost never take place, and decisions are reached by consensus, defined as "the absence of explicit, significant and strong dissent" (Portugal 2005:90-91). Importantly, consensus is gauged according to the number of Board members objecting, not the voting shares they command. As former Brazilian Director Murillo Portugal (2005:91) explains, this approach offers power resources to developing countries that are "larger than their share of votes," and opens the "possibility of having greater influence in policy decisions." In cases of dissent, the Managing Director (who both heads the bureaucracy and is the non-voting chairperson of the Board) seeks to bridge opposing positions and construct consensus, often by requesting additional research and policy reports from the staff. These dynamics of consensus formation, rather than formal voting, are common to IGOs (Martinez-Diaz 2009; Steinberg 2002).

The Board has wide authority to guide and control IMF policies, but staff are not accountable to Board members. Instead, they work within a bureaucratic structure (see Figure 1) that does not involve the Board; the Board can influence staff by communicating its will to the Managing Director (who is responsible for converting such messages into organizational practice). Staff are predominantly carriers of scientific norms that they are exposed to during their training in top economics departments (Nelson 2014). As Table 2 summarizes, 74 percent of all senior staff appointees between 1980 and 2000-hailing from 88 countriesreceived their training in Anglo-American universities, many of which hold considerable reputations for advancing theories of economic deregulation (most notably, the University of Chicago; see Dezalay and Garth 2002).

\section{[Table 2 here]}

To trace the dynamics of intra-IMF script-writing, we rely on hitherto unanalyzed material from the organization's archives. First, we collected the transcripts of all Board meetings pertaining to our case studies. Second, we gathered a range of IMF staff outputs that clarify staff opinions on favored 
normative changes and likely script content: memoranda and research notes, staff reports for discussion by the Board, and IMF publications and working papers on taxation and capital account issues. In addition, we conducted semi-structured in-depth interviews with key individuals involved: our initial interviews with IMF staff took place in 2005, with further rounds of interviews between 2008 and 2014, including staff in the Fiscal Affairs Department and the Monetary and Capital Markets Department. We complement these data sources with secondary literature.

\section{THE TECHNOCRATIC ORIGINS OF CONSUMPTION TAX NORMS}

The VAT is a consumption tax where tax credits can be claimed on inputs at all stages en route to final sale, thereby forcing producers, suppliers, retailers, and consumers into the fiscal-administrative system. This tax was first introduced in France in 1954; subsequently, it became a core component of economic policy harmonization in the European Union during the late-1960s. It was also adopted in South America in the 1960s, and in East Asia in the 1970s and 1980s. Significant further rollouts of VAT reforms occurred in post-Soviet and African economies in the 1990s. Figure 2, created by IMF staff, illustrates the impressive spread of VAT and its rapid adoption, especially between 1980 and 2000. Put simply, VAT became a bedrock of public finances in more than 130 IMF memberstates, providing between 20 and 33 percent of overall fiscal revenue (Ebrill et al. 2001; Keen and Lockwood 2010). ${ }^{4}$ Late adopters to VAT are typically countries with federal systems where national tax distribution issues pose political obstacles (Keen 2000), or countries under IMF-designed economic reform programs (Bird and Gendron 2007).

\section{[Figure 2 here]}

The rollout of VAT was an "unparalleled tax phenomenon" in the post-war capitalist order (Tait 1988:3), as it enabled states to move away from using trade tariffs from the mid-1970s onwards. Often at the behest of the IMF, approximately 30 percent of tariff revenues in developing countries were replaced by other forms of taxation, primarily VAT (Baunsgaard and Keen 2010). Implementation of VAT had two aims: to incorporate the informal sector into the tax system, and to create a tax less subject to political bargaining than were direct taxes such as personal income or corporation taxes (Joshi and Ayee 2008). Academic research in economics is more cautious about the merits of VAT 
introduction in developing countries, pointing to administrative capacity barriers to proper implementation and negative distributional implications (Stiglitz 2010). Nonetheless, global financialization trends and increased capital mobility placed pressure on developing-country governments - commonly via the IMF - to rely on VAT as the cornerstone of fiscal revenue generation.

\section{Policy script emergence within the IMF}

Despite the IMF's Articles of Agreement being silent on tax policy issues, the organization's Fiscal Affairs Department (FAD) has been described as the leading "change agent" in tax policy in developing countries (Bird and Gendron 2007:16). Since the early 1980s, FAD economists have held clear views on what constitutes appropriate tax policy: a heavy reliance on broad-based consumption taxes, such as VAT, ideally with a single rate and minimal exemptions; excise taxes on alcohol, tobacco, and petroleum; a rejection of tariffs; a simple personal income tax with limited deductions; and a low or moderate corporate tax rate (derived from Shome 1995). As this list makes clear, VAT undergirds the IMF staff's preferred tax policy norm.

At the same time, the IMF's Board has remained broadly silent on tax issues. For example, Vito Tanzi, longtime head of FAD (1981to 2000), stated that the Board "does not have an official view of tax reform," and tax opinions attributed to the IMF must be viewed as staff opinions (Tanzi 1994:465). The IMF staff view is also affirmed by a consensus among tax professionals on VAT as a "necessary modernisation of an essentially technical character" to all fiscal systems (Fjeldstad and Moore 2008:241). Consequently, VAT is a clear example of consensus on a policy script (quadrant 2 in Table 1): there is consistent policy activity from the staff, and the Board never devoted explicit attention to the script.

A group of policy economists - initially, Tanzi and Alan Tait and, more recently, Michael Keen - were the leading actors within FAD on VAT-related issues, and they developed the IMF policy view on VAT. As Figure 3 shows, this view crystalized early on in the form of an explicit policy script, detailing how VAT could be rolled out in "about eighteen months" in a given country (Tait 1988). Tait, the IMF economist who authored the VAT script, argued that the "more examples [of VAT] there are to follow, the less likelihood of mistakes. Legislation and regulations can be adopted to suit the particular contingencies of a country, but it is better to have half a dozen alternative laws and experiences to start 
from than none at all" (Tait 1988:25). Once VAT has been established following the IMF script, the "power of its inner logic is likely to be felt more strongly" (Ebrill et al. 2001:199), and more countries would follow suit in adopting the norm of shifting tax burdens onto mass consumption.

\section{[Figure 3 here]}

Part of the staff's logic here was the separation of science and politics. During our fieldwork, IMF officials recognized that a country's tax-to-GNP ratio is a political choice, and they sought to offer tax advice that would provide a stable revenue stream. ${ }^{5}$ IMF staff also supported VAT because it is "grounded on solid microeconomic foundations" (Frenkel and Razin 1988:19). Furthermore, IMF staff saw VAT as a core pillar of economic globalization and a policy issue of regional and global relevance, rather than solely as a national concern. This is for two reasons. First, approximately half of VAT in developing countries is collected at the border (Baunsgaard and Keen 2010). VAT works best in an open trading economy, and IMF staff view VAT as a means to compensate for lost tariff revenue and to provide fiscal stability that would also permit capital openness (Zee 2000). Second, IMF staff have a relatively free hand at diffusing the VAT policy script, as they consider national-level institutional memory over tax issues to be weak, especially after regime change. ${ }^{6}$ In turn, IMF staff can brand the introduction of VAT as good science to be adopted by all IMF member-states, rather than as a contentious policy issue that raises battles between memberstates.

\section{Institutionalizing the policy script}

Script institutionalization within the IMF on VAT occurred through a growing scientific consensus on how to treat common hurdles in a depoliticized manner. This permitted the creation of best-practice scripts that were institutionalized within the IMF and then rolled out via IMF staff and external experts who shared the same rationalization (Broome and Seabrooke 2007). For example, because transition countries faced serious problems with tax arrears from enterprises, Tanzi (1992) reflected that - in the post-Soviet context - tax arrears were not simply an institutional problem but also a political problem (see also Walder, Isaacson, and Lu 2015). The solution was to introduce a less visible tax, and to retrain finance ministries and tax departments to collect it. Policy scripts to assist with tax collection were subsequently taught to officials through training centers, such as the Joint Vienna Institute, which was established in 1992 and 
has since trained more than 32,000 officials to follow IMF policy scripts (Broome and Seabrooke 2015).

Tax policy professionals hired by the IMF followed the institutionalized policy script described above (Shome 1995; Tait 1988). Variations from the IMF approach to VAT were not permitted (Bönker 2006), and the Organisation for Economic Co-operation and Development (OECD) supported the IMF view, giving the overall "impression that a consensus had been formed and that fiscal reform should be technical rather than political" (Appel 2011:34). In transnational economic policy thinking, a flat tax that cuts across sectors was a popular alternative to VAT in post-communist Europe. The IMF directly opposed such policies, with Tanzi dismissing flat taxes as inappropriate for economies dealing with significant income inequality (Appel 2011). The importance of having a tax system that would permit closer economic integration with the European Community (which already had VAT) was highlighted as a key advantage of the tax reforms (Gehlbach 2008).

Consistent with the arguments of IMF staff that the Board had - at best - a marginal role in institutionalization of the VAT policy script, we did not identify a single Board discussion devoted to tax policy issues. This is in marked contrast to Board debates over capital account liberalization (discussed below) that took place every two to three years. The Board's lack of attention and scrutiny over the bureaucracy, while it remained informed about its practices in the field of taxation, is a sign of consensus over the staff-generated VAT policy script.

To test the robustness of this finding, we examined Board discussions over IMF lending to Tanzania. We selected this case inductively: Tanzania stands out as one of the countries with the most IMF-mandated tax policy reforms between 1985 and 2014 (Kentikelenis et al. 2016), and our interviewees noted it as a case involving top IMF economists. Our analysis reveals that state representatives discussed Tanzania's tax reforms and supported staff preferences on VAT. For instance, in 1992, IMF staff wanted Tanzania to introduce VAT in the near future (IMF 1992c). In the Board discussion, Indonesian Director Ismael suggested that Tanzanian authorities "adopt a comprehensive tax reform program, including the introduction of a broad-based value-added tax, to broaden the tax base and attain fiscal viability" (IMF 1992b:17), a view also endorsed by British Director Dorrington (IMF 1992a:7). 
A few years later, Tanzania's lending agreements with the IMF mandated and micromanaged the introduction of VAT. During Board deliberations, Directors commented on the merits of VAT compared to other taxes. For example, German Director Donecker noted that "a more rapid introduction of the value-added tax would not only improve the revenue situation but also allow a faster reduction of custom tariffs" (IMF 1996a:24), a position echoed by the Russian representative (IMF 1996a:38). Reflecting these endorsements, IMF-mandated reforms for the country included a condition for "VAT legislation to be passed by Parliament" (IMF 1996b:59). ${ }^{7}$ Throughout Tanzania's subsequent interactions with the IMF, the staff's promotion of VAT reforms and rejection of tax alternatives was adamant (Fjeldstad and Moore 2008; IMF 2000a, 2000b, 2001b). In the 2000s, the Board reiterated its support for VAT and urged staff to offer Tanzanian authorities further assistance on these issues (IMF 2002, 2006).

In summary, IMF staff engaged in consistent policy activity, and the Board never devoted ad hoc and explicit attention to the VAT script, despite being wellinformed about staff activities in designing tax reforms. To the extent that the Board considered IMF-mandated tax reforms to borrowing countries, Directors endorsed the staff script on VAT introduction. Consequently, we identify the IMF's views on VAT as an instance of consensus over a policy script, which enabled its successful institutionalization and subsequent diffusion.

\section{THE CONTENTIOUS POLITICS OF CAPITAL CONTROLS}

In the late 1980s and 1990s, the attempt to institutionalize capital account liberalization - that is, the reduction of restrictions on capital flows between countries - was a prominent international economic policy issue. For proponents of capital openness, the promise was higher output, increased efficiency, and greater economic stability (see Fischer 1998). Capital was understood to be like any other good, and its free movement was expected to spur benefits for lenders and borrowers. Critics countered that unregulated capital movements were an inherent source of instability, as speculative flows and capital flight could wreak havoc even in economies with sound macroeconomic fundamentals (Stiglitz 2000).

Given its "globalizing mission" (Woods 2006), the IMF was the most prominent participant in the global norm-making process over capital account liberalization. One aspect of this process proved uniquely controversial: the use of capital controls; that is, the direct regulation of inflows and outflows of capital. The IMF's Articles of Agreement explicitly permitted reliance on such controls: 
"Members may exercise such controls as are necessary to regulate international capital movements" (IMF 2011:20). This is unsurprising, as the organization is the offspring of British economist John Maynard Keynes, an ardent opponent of globalized finance (Keynes 1943). Yet, as academic and policy debates centered on the merits of capital openness in the 1970s and 1980s, the organization's ability to promote related policies attracted attention. As Figure 4 shows, many advanced industrialized economies and pockets in the developing world embraced capital openness starting in the 1970s, but it failed to take off as a global norm in the 1980 s and 1990s.

\section{[Figure 4 here]}

In this section, we trace script-writing in the IMF vis-à-vis capital controls, a key issue in broader debates over capital openness norms. Was this a world-cultural process of scientization, or was it political and contentious? Prominent accounts in political science focus on how IMF staff came to believe that capital controls were unworkable, with politics and contention operating only in the background (Abdelal 2007; Chwieroth 2010). Challenging this argument, we show that staff preferences did not develop independently of their political masters. Instead, power asymmetries on the IMF's Board explain the legitimation basis staff drew on to advance their preferred script. We document that the Board debated capital openness in regular intervals, and that Board members expressed clear views on the topic. By re-embedding staff preferences into Board dynamics, we demonstrate the recursive process of staff and Board interactions that codetermined script emergence and institutionalization attempts.

Policy script emergence within the IMF

Initial discussions over capital controls in the work of the IMF started in the mid-1980s, when - at the request of the Board-IMF staff considered relevant issues. At the time, the IMF was assessing the costs and benefits of multiple currency practices $^{8}$ that governments used to control capital movements. A staff report confirmed that the IMF refrained from pronouncing judgments on its members' practices relating to capital movements, as the Board had "not yet settled the issue expressis verbis" (IMF 1985:2). However, at the same time, staff made the case for gaining jurisdiction over these practices. In this view, there was economic and legal support for extending the IMF remit into this area, as this "would contribute to policy consistency" (IMF 1984:18; 1985). Expanding the 
IMF's authority over the capital account would lead to less regulation of crosscountry capital movements.

This interpretation gained no traction on the Board. For example, German Director Grosche noted that he "could not easily accept the staff's argument" (IMF 1985:3), and Dutch Director de Groote found the staff arguments "somewhat contrived ... [due to the attempt] to extend the Fund's jurisdiction to [issues that] did not fall within the Fund's legal province" and complained that staff tried "to force an interpretation on the Executive Board" (IMF 1985:5-6). Indeed, French Director de Maulde emphasized that "the selective treatment by the staff of the Articles of Agreement . . . did not reinforce the credibility of the Legal Department" (IMF 1985:10). Other representatives from industrialized and developing countries raised similar concerns during the discussion.

Importantly, two key Directors supported staff positions: Charles Dallara from the United States and Nigel Wicks from the United Kingdom. Dallara acknowledged that the economics of the issue were contentious, but he favored the staff's interpretation of the mandate, despite other Board members' serious reservations: "If the Board accepted the staff's legal opinion . . . [the IMF] would have the duty of exercising the jurisdiction emanating from the legal analysis' (IMF 1985:12-13).

Unable to garner requisite support, this attempt-initiated by staff and supported by some powerful Directors - at granting the IMF jurisdiction over a form of capital controls failed. Given this unfavorable outcome, staff retreated to a less contentious activity: producing research on the topic (Dooley 1988; Dooley, Frankel, and Mathieson 1988; Gros 1987). To give new thrust to this work, the IMF recruited two economists from the University of Chicago, a locus of pioneering research that prescribed limiting government intervention in the economy (Dezalay and Garth 2002). Most importantly, Chicago-trained Jacob Frenkel was hired in 1987 to head the IMF's research department. Frenkel was aided by Michael Dooley, author of several IMF studies on capital account liberalization and formerly a faculty member in Chicago's economics department.

In 1990, staff returned to the issue with their first systematic treatment intended for discussion by the Board (IMF 1990b). This 90-page report noted with concern that-compared to industrialized countries - developing countries generally regulated capital flows, even though "experiences with capital flight . . . suggest that these restrictions are far from effective" (IMF 1990b:66). Staff reported "a 
growing consensus that capital flight needs to be addressed by dealing with the underlying distortions or policy inadequacies at the source, rather than by attempting to restrict the symptom or manifestation of these inadequacies (i.e., the capital flow itself)" (IMF 1990b:66).

This time, staff proposals were greeted with more enthusiasm by Board members from high-income countries. Nonetheless, some Directors took issue with the assertion that removal of capital controls forces governments to adopt "sound" economic policies. For instance, Saudi Director Al-Jasser posited that staff insights "[do] not often apply to developing countries" (IMF 1990a:19), as their economic systems were fundamentally different from those of industrialized countries. However, the overall tone of the discussion was favorable toward dismantling capital controls. As Spanish Director Fernandez Ordonez noted:

If we all [i.e., the Board] agree that the possibility of imposing restrictions on capital flows is an instrument that should never be used by governments, the time has come for this consensus to become law. We should initiate a process to arrive at an international agreement on the freedom of capital flows. . . In my view, the Fund is well placed to play a role here. (IMF 1990a:2021)

In summary, by the early 1990s, staff and powerful shareholders agreed about the desirability of extending IMF jurisdiction over capital controls. The emerging script was simple: capital controls were ineffectual, counterproductive, and props for misguided economic policies. Their removal would only spur benefits. Nonetheless, given the IMF's restrictive mandate and the dissent of representatives from developing countries, no concrete policy changes occurred, other than staff research to support the script. In 1991, Frenkel left the IMF's research department and was replaced by Michael Mussa, who studied in Chicago at the same time and under the same supervisor as Frenkel. Prior to this appointment, Mussa was an economics professor at Chicago and a member of Ronald Reagan's Council of Economic Advisers (1986 to 1988).

\section{Contentious efforts to institutionalize policy script}

Building on the support for capital account liberalization by major shareholders on the Board, staff started incorporating such proposals in their policy advice and technical assistance to member-states. For instance, IMF missions to Korea, 
Chile, and Botswana "encouraged" the removal of capital controls (IMF 1995b:10). Yet, even though staff admitted their "general distaste for such controls" (IMF 1995b:10-11), the Articles of Agreement prohibited direct action on the topic. Staff raised the issue of whether the IMF should adhere to the mandate's provisions, which "were framed in a different era, and are no longer in harmony with the new international system," or extend the IMF's jurisdiction to cover capital account issues, which would have "clear systemic benefits" for the world economy (IMF 1995b:15). In short, staff were attempting to institutionalize their preferred "no capital controls" script by enshrining it in the mandate, thereby giving them automatic responsibility to diffuse ("harmonize") the norm across the world.

This script-institutionalization attempt proved controversial among Board members. Directors from high-income countries praised the staff analysis, which "adds impressive ammunition" to liberalization efforts (Canadian representative in IMF [1995c:4]). U.S. Director Lissakers commended Michael Dooley, author of the literature review that informed the staff recommendations (IMF 1995a), for "remind[ing] us that there is a compelling theoretical argument that free capital movements are likely to be welfare enhancing, identical to the argument for the gains from trade in goods and services. . . . Careful research suggests capital controls are more frequently a device for preserving suboptimal macro policies" (IMF 1995c:22).

For Directors from high-income countries, the evidence presented by staff was adequate to conclude that removing capital controls was desirable, as they only "impair the efficient allocation of resources [and] preserve vested interests" (German representative in IMF [1995c:27]). As Swiss Director Kaeser suggested, "[C]apital account liberalization should be an irreversible process . . . [because] economic agents prefer to act in an environment in which the rules of the game are predictable" (IMF 1995c:14). Furthermore, U.S. Director Lissakers noted that the United States "would also be willing to look seriously at the idea of amending the Articles of Agreement" to institutionalize the "no capital controls" script (IMF 1995c:26).

Notwithstanding such enthusiastic endorsements, representatives from developing countries were skeptical. These countries had grown cautious of liberalized capital flows due to their own experiences with financial crises over the 1980s and early 1990s, as well as domestic political opposition to such measures - often in the form of mass protests (Wade and Veneroso 1998a; Walton and Ragin 1990). Some 
developing countries had also been historically opposed to relaxing their capital controls, viewing it as against their national interests and the ideologies of their dominant political parties. This was particularly the case in communist countries where capital liberalization was considered antithetical to maintaining a command economy (Quinn and Toyoda 2008). Overturning such preferences in the post-communist period required not only a strong IMF script, but also domestic economic experts willing to endorse the script as normatively appropriate - in many cases, this was difficult to achieve (Bockman and Eyal 2002). For other developing countries, capital account liberalization was viewed as an unnecessary and unjustified imposition (see Wade 2001). For example, in a Board meeting, Malaysian Director Cheong led the attack on the staff report for misrepresenting country experiences and disagreed with the staff's conclusion "that capital control measures delay policy adaptations" (IMF 1995c:6). Instead, such measures "provided a breathing space to enable more fundamental macropolicies to be implemented subsequently" (IMF 1995c:6), a comment repeated by the Chinese, Colombian, Indian, Iranian, Venezuelan, and other Directors. Hinting at double standards for developed versus developing countries, Russian Director Tulin complained:

The fact that a vast majority of the industrial countries had exercised controls on capital flows for decades, until they felt themselves prepared to liberalize their regulations, attests to the nonincidental nature of this phenomenon. General and unqualified appeals to remove capital controls from industrial nations known for recent sophisticated protectionism in this area would not sound very convincing to the rest of the world. (IMF 1995c:50)

To support their positions, Directors from developing countries drew on the experiences of their own countries, and reports by the IMF's sibling institution, the World Bank, that suggested short-term capital controls made "eminent sense" (IMF 1995c:48). These Directors attacked the economic logic of staff arguments and put forward a joint line that the use of "capital controls may be decided by [national] authorities at their own discretion and without review by the Fund" (Iranian representative in IMF [1995c:9]). The existing mandate was sufficient to allow the Fund to provide informal suggestions on the use of capital controls, "without making [liberalization] an end in itself" (Indian representative in IMF [1995c:58]). 
Even though Directors from high-income countries (i.e., countries holding the most votes) supported the "no capital controls" script, the Board did not reach consensus over the desirability of amending the Articles of Agreement. Consequently, no decision was made, and the Board agreed to revisit the issue in the future. Reacting to this outcome with disappointment, U.S. Director Lissakers said the United States "would not rule out further consideration of an amendment of the Articles at a relatively early date," and suggested the Board should "revisit the issue sooner rather than later" (IMF 1995c:71).

The 1995 attempt of IMF staff and powerful shareholders to institutionalize their preferred policy script drew on frontier academic work and the IMF's own research and policy proposals. These bases of legitimation for the new scriptgiving the IMF jurisdiction to demand removal of capital controls - were cast into doubt due to contention on the Board. In a concerted effort, Directors from developing countries managed to forestall treaty changes by drawing on a portfolio of strategies: articulating their countries' experiences, emphasizing the adequacy of existing arrangements, and framing the merits of the script as a topic under debate (rather than reflecting universal acceptance of the script, as staff and representatives from high-income countries contended).

Following the failed 1995 attempt to institutionalize their preferred script, IMF staff initiated a data collection project on capital controls, as "a central element of the Fund's intensified efforts in this area" (IMF 1997h:4). This research led staff to reiterate their calls for expanding IMF jurisdiction (IMF 1997b). As a concession to developing countries, staff acknowledged that the temporary imposition of capital controls may in some instances be beneficial, although these cases would require explicit IMF approval (IMF 1997a, 1997g). Even so, staff admitted that this approval was unlikely to ever be granted, given that the organization had "never found it necessary to formally request a member to impose capital controls" (IMF 1997b:28).

These staff proposals still elicited objections from developing countries, and several Directors engaged in a concerted effort to prevent script institutionalization. For instance, Indian Director Sivaraman disagreed with putting the IMF "in a final position to approve such temporary controls which could mean that the Fund impinges on the prerogatives of governments to do what is best to prevent a crisis in their country" (IMF 1997c:7), a remark echoed verbatim by the Indonesian representative (IMF 1997c:31). In a draft report for the Interim Committee - a decision-making body overseeing the Executive Board 
and composed of 24 finance ministers-IMF staff suggested that capital account liberalization should not only be under IMF jurisdiction, but it should also become one of the purposes of the organization (IMF 1997e:2-3). Commenting on this draft, several Directors chastised the staff for promoting an issue that "had not been discussed in the Board" and pointed to the lack of overall consensus (IMF 1997d:5).

At the time of these discussions, the Asian financial crisis captured global attention. Starting in Thailand and spreading to other countries, the crisis became pivotal for the IMF's attempt to institutionalize a script in support of capital openness as a global norm. The crisis was intricately linked to capital account issues: Indonesia, Korea, Malaysia, the Philippines, and Thailand had received net private capital inflows of $\$ 93 \mathrm{bn}$ in 1996 , which reversed to $\$ 12.1 \mathrm{bn}$ in outflows in 1997 (Radelet and Sachs 1998). Commercial banks and portfolio investments were key contributors to these outflows; both had been identified by representatives from developing countries in Board meetings as important capital flows requiring regulation.

The crisis fueled debates over the merits of capital controls at a time when it appeared that IMF staff and powerful members were close to achieving their preferred outcome: expanding IMF jurisdiction to cover these issues. Several prominent economists suggested that open capital markets were partly to blame for the crisis, which may have been avoided had these countries maintained use of capital controls (Bhagwati 1998; Rodrik 1998; Wade and Veneroso 1998b).

Responding to such criticisms, IMF staff argued that few - if any-links existed between the Asian crisis and capital account liberalization. The IMF's flagship World Economic Outlook attributed the crisis to underlying domestic policies (IMF 1997f:2), and Stanley Fischer (1998:2), the IMF's First Deputy Managing Director, commented that "the Asian crisis forcefully raises the questions of whether capital-account liberalization has moved too quickly. . . I reject this view." As Fischer (1997) explained shortly after the onset of the crisis, capital account liberalization "is an inevitable step on the path of development, which cannot be avoided and therefore should be adapted to. In support of this view, we may note that all the most advanced economies have open capital accounts." Speaking to an audience of Asian policymakers, Fischer (1997) noted that he wanted "to persuade those of you who remain skeptical about capital account liberalization ... that an amendment of the Fund's Articles of Agreement is the best way of ensuring that [it] is carried out in an orderly, non-disruptive way." 
Advancing similar arguments, IMF Managing Director Camdessus told the Board that "the Asian crisis had been a powerful argument for added jurisdiction. If it were to rely on technical assistance and surveillance, the Fund would not be able to prevent such crises from happening again" (IMF 1998b:9). U.S. Director Lissakers agreed that the Asian developments called "for speed and some ambition in our amendment [of the Articles]' (IMF 1998b:10). Other Directors from high-income countries further supported expanding IMF jurisdiction, and they took issue with accounts of the Asian crisis that accorded a role to free capital flows. For instance, Icelandic Director Palmason disagreed with thenWorld Bank Chief Economist Joseph Stiglitz, who pointed to the utility of capital controls in helping countries deal with large-scale financial outflows. Instead, Palmason supported the views of Charles Dallara, head of the international bank lobby and formerly U.S. Director at the IMF, who argued that introduction of controls was not an appropriate way of balancing capital flows (IMF 1998b).

Nonetheless, the tide against script institutionalization was turning. Even U.S. Director Lissakers acknowledged that - in light of the Asian crises - several IMF member-states wanted to challenge the "no capital controls" script, "which I think is a terrible idea, but so be it" (IMF 1998b:10). Indeed, many Directorsmostly from developing countries - raised important challenges to the view that capital controls were ineffective, and that the benefits of capital account liberalization outweighed any potential costs (Egyptian, Indian, Russian, and Zimbabwean representatives in IMF [1998b]). Furthermore, the purported economic merits of removing capital controls - promoted by staff-now came under increased scrutiny and were characterized as "misleading" (IMF 1998a:56). By early-1999, several Directors were explicit about their skepticism toward expanding the IMF's jurisdiction (Angolan, Canadian, Egyptian, Indian, Japanese, Saudi, and Thai representatives in IMF [1999]). Some high-income countries still supported an amendment, but-compared to the pre-Asian crisis period-momentum was lost. Proposals for changing the Articles soon ceased altogether.

What does the failed attempt to institutionalize the "no capital controls" script suggest about intra-organizational script-writing? From the onset, this was a contentious process that manifested in power struggles on the Board. The staff and powerful IMF members sought to institutionalize their preferred script in various ways - for example, by producing research, advancing a new 
interpretation of the mandate, or misrepresenting developing countries' concerns. At the same time, representatives from the developing world - often under the pressure of social and political unrest in their home countries or inspired by anticapitalist ideologies - attempted to stave off script institutionalization by relying on a portfolio of strategies: building coalitions, repeating the same message, casting their disagreements in terms of economic theory, contesting unsubstantiated claims by staff or other Board members on the presence of consensus, and pointing to their countries' positive experiences with the use of capital controls.

World-cultural aspects emphasized by World Polity accounts - such as the role of ideas and the training of experts - enter the story as important variables informing theorization processes. For instance, key advocates of dismantling capital controls were trained at the notoriously neoliberal Chicago economics department, and high uniformity in staff educational backgrounds contributed to shared worldviews over appropriate economic policy (see Table 2). Yet, recourse to economic knowledge produced by this close-knit network was not adequate to institutionalize their preferred script. Instead, such elements were primarily relevant as "ammunition" for Board members hostile to capital controls (IMF 1995c:4).

\section{DISCUSSION AND CONCLUSIONS}

This article examined the emergence and attempts at institutionalization of policy scripts within an important IGO: the International Monetary Fund, one of the "paramount institutions of global norm-making" (Halliday 2009:264). We outlined how intra-organizational script-writing works, capturing contention or consensus among IGO staff and the board of directors (where member-states are represented). Because script-writing both follows norm emergence and is prior to policy diffusion, these dynamics are an integral part of the mechanisms underpinning how policy ideas are spread around the world. We opened this black box, and provided conceptual tools to analyze its contents. We presented a model that elaborates on three types of interactions pertaining to these processes: among IGO staff, within the board of directors, and between staff and board. Our model points to how consistent or mixed policy activity from IGO staff and attention or inattention from boards of directors matters for scriptwriting. 
Focusing on these interactions, we scrutinized script-writing within the IMF over two policy issues in support of global norm-making: VAT implementation to support state reliance on consumption taxes, and capital account liberalization to support capital openness. In the case of VAT, relative inattention from the Executive Board allowed staff to institutionalize their preferred policy script, which was carefully constructed, and defended, over time and on the basis of academic theories. To the extent that the Board intervened in staff practices, it supported diffusing the staff-generated script. VAT provides an example of a tightly controlled script - to replace trade tariffs with higher tax burdens on the general population-without significant domestic opposition or transnational activism. ${ }^{9}$ In the case of capital controls, normative contention in the Board prevented the institutionalization of this script, despite its support from powerful staff and member-states. Developing countries - skeptical about the merits of liberalized capital markets due to ideological preferences or public protestssuccessfully countered attempts at legitimating script institutionalization, and they consistently and collaboratively contested the logic of the script. In short, world-cultural resources - like claims to global scientization and rationalizationwere not sufficient to trump the political aspects of the process, and actors leveraged the institutional environment to obstruct script institutionalization. Building on these findings, Figure 5 presents our understanding of the likely loci of politics and science in script-writing in IGOs.

\section{[Figure 5 here]}

Our account has important implications for understanding script-writing within international organizations more generally. We suggest that opening intraorganizational black boxes is necessary for explaining how power asymmetries determine which scripts become dominant. Power asymmetries-manifested in recursive rounds of intra-organizational deliberations - can also explain instances of widespread script institutionalization, despite contention in the countries affected and from other international organizations involved. The case of user fees for access to health services in developing countries provides a case in point: in the 1980s - despite vehement resistance from developing countries and the World Health Organization - the World Bank and UNICEF diffused a policy script introducing charges for healthcare access that promised to increase efficiency and resources, and to better provide services to those in need (Chorev 2012b; Gilson and McIntyre 2005). In another example, the worldwide liberalization of criminal laws related to sexual activities was inextricably linked to international organizations - whether IGOs or INGOs-promoting penal reform through 
various means (Adam, Duyvendak, and Krouwel 1999; Frank, Camp, and Boutcher 2010), despite some states' strong resistance to such norms (Ayoub 2015).

Our model can be applied to help understand the interplay between scientized and political decision-making in a range of cases where a focal organization leads script-writing. For example, the establishment of the UN High Commissioner for Refugees in the 1950s resulted in scientific and political debates over what kind of protection the organization would provide to refugees: the United States promoted a narrow legal assistance script, whereas European countries and human rights lawyers favored a script that entailed legal, material, and logistical assistance. In this instance, the U.S. script prevailed (Barnett and Finnemore 2004; Kennedy 1986). In another case, in 1989, Japan spearheaded an attempt to push the World Bank to acknowledge the merits of sectoral industrial policies financed by government-subsidized loans; a script that flew against the prevailing neoliberal orthodoxy. Many developing countries on the Board supported rethinking the Bank's script on financing regimes for industrial development, but Bank staff and the United States strongly resisted the move and asserted the merits of market-determined interest rates. In concert, U.S. officials and Bank staff successfully staved off the attempt to introduce the new script by questioning the causal link between government-subsidized loans and industrial development, and by accepting some minor-if not trivial-nuancing of the dominant anti-industrial policy script (Wade 1996).

Focusing on tensions between science and politics also helps explain policy design conflicts in international organizations with more complex organizational structures, such as the European Union (EU) and the Organisation for Economic Co-Operation and Development (OECD). Within the EU, the Commission forms the bureaucratic arm of the organization, and the Council (composed of state officials) and Parliament (composed of directly elected parliamentarians) form conduits to transmit political pressures. Since the onset of the European economic crises in 2008, the Commission extended its powers by developing new policy scripts, like the Macroeconomic Imbalance Procedure, that yielded contention within the Council and the Parliament and political challenges to the Commission (Schmidt 2016). In the OECD, scripts emerge from interactions between the science of the Secretariat and specialist Committees, and the politics of the Council. This design rewards innovation while placing limits on what is acceptable (Marcussen and Trondal 2011). For example, when the OECD promoted a script to combat financial secrecy, "political disagreement between 
members [broke] through and supersede[d] consensual technocratic problemsolving" (Sharman 2012:26; see also Broome et al. 2017). In both cases, tensions between science and politics in script-writing hold important explanatory value.

As World Polity literature has long established (Boli and Thomas 1999), INGOs can also act as key global script-writers, and they often exhibit similar scienceversus-politics dynamics in this process. For example, Human Rights Watch (HRW) initially was a leading script-writing organization in the global campaign against small arms. In the 1990s, the organization drew on its legal expertise to develop a script on halting the proliferation and misuse of small arms in conflict settings. Yet, over the 2000s, HRW substantially scaled back its efforts in this area: its political masters believed this work would bring them in collision with the U.S. National Rifle Association - a powerful player in U.S. domestic politicswhich could, in turn, endanger their collaboration with the U.S. government in the Iraq and Afghanistan conflicts (Stroup and Wong 2017). In another case, in the mid-1980s, Amnesty International considered including issues related to sexual orientation in assessments of human rights violations: western constituencies advocated a script that included orientation in how the INGO defined sex in its statutes, given the weight of evidence documenting imprisonments due to sexual orientation. The change was made in 1991: dealmaking between western and non-western constituencies in the INGO's governing body resulted in granting the staff remit to devote attention to human rights violations related to sexual orientation, as long as they also worked on issues of key relevance to Palestinians (Hopgood 2006). As these examples suggest, intraorganizational tensions over modes of script-writing are also present in INGOs acting (or seeking to act) as focal points in global norm-making.

Two avenues of future research can enhance our understanding of how global norms emerge and are institutionalized. First, subsequent work can cast light into a black box that remains in our own analysis: we understood state-appointed IGO board members as representing state interests, and IGO staff as conduits for scientific ideas. Nonetheless, political sociologists analyzing national-level political officials and bureaucrats have long pointed to intricate and interconnected powerelites (see Mills 1956; Mizruchi 1996). International policy-making need not be different, and scholars have pointed to revolving doors between business, international organizations, think tanks, and governments (Tsingou 2015; Wedel 2001). These links may substantially affect the types of theorization and rationalization taking place at the transnational level. 
Second, at a macro-analytical level, fundamental transformations in global governance are underway. International organizational and normative orders are becoming more heterogeneous and decentralized (Babb and Chorev 2016), and hybrid models of international organization governance are emerging (Abbott et al. 2015; Mattli and Seddon 2015; Seabrooke and Henriksen 2017). For example, the global health field is rapidly changing, as the governing bodies of key organizational actors - like the Global Fund to Fight AIDS, Tuberculosis and Malaria, and the Global Alliance for Vaccines and Immunization-include representatives from states, IGOs, INGOs, national NGOs, the private sector, and private foundations (Clinton and Sridhar 2017). Similar transformations are taking place in global environmental governance (Green 2014; Henriksen and Seabrooke 2016). Further, new modes of "experimentalist" transnational governance entail joint decision-making by IGOs and states - with input from civil society - on the basis of feedback from the implementation of policies at the local level (see Overdevest and Zeitlin 2012; Zeitlin 2015). These shifts in global governance affect how power asymmetries operate, and future research can unpack these novel intra-organizational dynamics: science, politics, private interests, and moral concerns interact in ways that are insufficiently understood but have significant implications for the norms diffused around the world.

Changes in global script content have important real-world effects on socioeconomic outcomes. Yet, these changes are neither natural nor inevitable: they depend on scientific and political attempts at transforming institutional orders. Our account leveraged the internal dynamics of international organizations, and the power asymmetries therein: these intra-organizational tensions spill over into how global norms are received and translated. Specifying the processes beneath what becomes rationalized and diffused illustrates how norms can be contested, even if the overall framework of global capitalism is not. At the same time, tracing conflict between science and politics in script-writing reveals where claims to the universality of world culture go too far or where power politics are the key drivers of normative transformation. 


\section{APPENDIX}

Table A1. Voting Shares of IMF Membership

\begin{tabular}{lllll}
\hline & & 1981 & 1991 & 2001 \\
\hline Major & United States & $20.01 \%$ & $18.89 \%$ & $17.16 \%$ \\
& United Kingdom & $6.99 \%$ & $6.55 \%$ & $4.97 \%$ \\
& Germany & $5.16 \%$ & $5.71 \%$ & $6.02 \%$ \\
& France & $4.60 \%$ & $4.74 \%$ & $4.97 \%$ \\
& Japan & $3.98 \%$ & $4.47 \%$ & $6.16 \%$ \\
& China & $2.89 \%$ & $2.54 \%$ & $2.95 \%$ \\
Remaining & Saudi Arabia & $1.69 \%$ & $3.40 \%$ & $3.24 \%$ \\
Shareholders & Russia & Non-member & Non-member & $2.76 \%$ \\
& High-income countries & $21.39 \%$ & $21.10 \%$ & $24.39 \%$ \\
& Middle-income & $22.14 \%$ & $21.94 \%$ & $18.31 \%$ \\
& countries & & & \\
& Low-income countries & $11.15 \%$ & $10.65 \%$ & $9.10 \%$ \\
& Total: & $100 \%$ & $100 \%$ & $100 \%$ \\
\hline
\end{tabular}

Source: IMF (1981, 1991, 2001a). 


\section{Acknowledgments}

We thank the ASR editors, three anonymous reviewers, Tim Bartley, André Broome, John L. Campbell, Susanna Campbell, Timon Forster, David Lake, Peggy Levitt, Stephen Nelson, Eva Østergaard-Nielsen, Ole Jacob Sending, Amanda Shriwise, Duncan Snidal, Sarah Stroup, Thomas Stubbs, Robert Wade, Marc Ventresca, and Jocelyn Viterna for insightful comments and suggestions; all remaining errors are our own. We are grateful to Timon Forster for providing invaluable research assistance. AK also thanks the Transnational Studies Initiative at Harvard University's Weatherhead Center for International Affairs, which provided an intellectual home while the research for this article was undertaken.

\section{Funding}

AK acknowledges financial support by the Cambridge Political Economy Society Trust, and the Centre for Business Research at the Cambridge Judge Business School. LS acknowledges financial support from the European Research Council's "Professions in International Political Economies" (\#263741-PIPES) project, and the "Hybrid Networks in Transnational Governance" project at the Copenhagen Business School.

\section{Notes}

1. Scripts are distinct from more general organizational policy positions: the latter can be abstract preference statements, whereas the former identify specific - but generalizable - measures to be taken to address a policy issue. For instance, the World Bank has a policy position that tax avoidance is deleterious to economic development (World Bank 2015), but it has not developed comprehensive recommendations on how countries can curb it. In contrast, the UN High Commissioner for Refugees both identifies that refugees are entitled to legal protection and spells out how this protection is to be provided (Kennedy 1986).

2. Our conceptualization of actors is compatible with Hironaka's (2014:78) work on agents - a weaker version of actors, encompassing states, organizations, and individuals, who "enact roles enabled by institutional structures [and] actively interpret, elaborate, and expand institutional rules and discourses." Like Hironaka (2014) and the World Polity school (Schofer et al. 2012), we do not subscribe to a notion of all-powerful free-floating actors. Nonetheless, World Polity literature often relies on the concept of agents to refer to international organizations (Hironaka 2014). To avoid terminological ambiguities of discussing 
agents nested within other agents, we refer to IGO staff and state representatives as "intra-organizational actors."

3. According to this norm, knowledge that credit will become available in case of a financial crisis increases the likelihood of a crisis, as governments lack incentives to introduce crisis-prevention policies. Consequently, coercive conditionalities can discourage governments from considering credit by international financial institutions as an attractive option.

4. The United States never adopted VAT, but state sales taxes are similar.

5. Author interview with Senior Economist, IMF Fiscal Affairs Department, May 2005.

6. Author interview with Senior Economist, IMF Fiscal Affairs Department, May 2005.

7. The sole dissenting remark was by U.S. Director Lissakers, who asked whether "land or property taxes, which I have an impression we tend to neglect" should be considered (IMF 1996a:12). Other Directors did not engage with these proposals, suggesting limited interest in veering off the established script.

8. Multiple currency practices refer to countries' use of transaction-specific exchange rates, instead of a single rate applying to all movements of goods, services, or capital. For example, a country may have used a regulated exchange rate for its major exports, and a market-determined rate for other transactions. Among other objectives, these practices sought to insulate countries from volatile or speculative capital flows (IMF 1984).

9. Activists have campaigned on tax issues like the Financial Transactions Tax and tax havens (Seabrooke and Wigan 2016), but VAT has not attracted the attention of the advocacy community despite being widely considered a regressive tax that places a heavy burden on the poor. 


\section{References}

Abbott, Kenneth W., Philipp Genschel, Duncan Snidal, and Bernhard Zangl, eds. 2015. International Organizations as Orchestrators. Cambridge, UK: Cambridge University Press.

Abdelal, Rawi. 2007. Capital Rules: The Construction of Global Finance. Cambridge, MA: Harvard University Press.

Adam, Barry, Jan Willem Duyvendak, and André Krouwel, eds. 1999. The Global Emergence of Gay and Lesbian Politics: National Imprints of a Worldwide Movement. Philadelphia: Temple University Press.

Appel, Hillary. 2011. Tax Politics in Eastern Europe: Globalization, Regional Integration, and the Democratic Compromise. Ann Arbor: University of Michigan Press.

Ayoub, Phillip M. 2015. "Contested Norms in New-Adopter States: International Determinants of LGBT Rights Legislation." European Journal of International Relations 21(2):293-322.

Babb, Sarah L. 2003. "The IMF in Sociological Perspective: A Tale of Organizational Slippage." Studies in Comparative International Development $38(2): 3-27$.

Babb, Sarah L. 2007. "Embeddedness, Inflation, and International Regimes: The IMF in the Early Postwar Period." American Journal of Sociology 113(1):128-64.

Babb, Sarah L. 2009. Behind the Development Banks: Washington Politics, World Poverty, and the Wealth of Nations. Chicago: University of Chicago Press.

Babb, Sarah L. 2013. "The Washington Consensus as Transnational Policy Paradigm: Its Origins, Trajectory and Likely Successor." Review of International Political Economy 20(2):268-97.

Babb, Sarah L., and Bruce G. Carruthers. 2008. "Conditionality: Forms, Function, and History." Annual Review of Law and Social Science 4(1):13-29.

Babb, Sarah L., and Nitsan Chorev. 2016. "International Organizations: Loose 
and Tight Coupling in the Development Regime." Studies in Comparative International Development 51(1):81-102.

Babb, Sarah L., and Alexander E. Kentikelenis. 2018. "International Financial Institutions as Agents of Neoliberalism." in The SAGE Handbook of Neoliberalism, edited by D. Cahill, M. Cooper, M. Konings, and D. Primrose. Thousand Oaks, CA: SAGE Publications.

Barnett, Michael N., and Martha Finnemore. 2004. Rules for the World: International Organizations in Global Politics. Ithaca, NY: Cornell University Press.

Ban, Cornel and Kevin Gallagher. 2015. "Recalibrating Policy Orthodoxy: The IMF Since the Great Recession." Governance 28(2):131-46.

Baunsgaard, Thomas, and Michael Keen. 2010. "Tax Revenue and (or?) Trade Liberalization." Journal of Public Economics 94(9-10):563-77.

Bhagwati, Jagdish. 1998. "The Capital Myth: The Difference between Trade in Widgets and Dollars." Foreign Affairs 77(3):7-10.

Bird, Richard M., and Pierre-Pascal Gendron. 2007. The VAT in Developing and Transitional Countries. Cambridge, UK: Cambridge University Press.

Bockman, Johanna, and Gil Eyal. 2002. "Eastern Europe as a Laboratory for Economic Knowledge: The Transnational Roots of Neoliberalism." American Journal of Sociology 108(2):310-52.

Boli, John, and George M. Thomas. 1997. "World Culture in the World Polity: A Century of International Non-governmental Organization." American Sociological Review 62(2):171-90.

Boli, John, and George M. Thomas, eds. 1999. Constructing World Culture: International Nongovernmental Organizations Since 1875. Stanford, CA: Stanford University Press.

Bönker, Frank. 2006. The Political Economy of Fiscal Reform in Central-Eastern Europe. Cheltenham, UK: Edward Elgar. 
Boyle, Elizabeth H., Minzee Kim, and Wesley Longhofer. 2015. "Abortion Liberalization in World Society, 1960-2009." American Journal of Sociology 121(3):882-913.

Broome, André, and Leonard Seabrooke. 2007. "Seeing Like the IMF: Institutional Change in Small Open Economies." Review of International Political Economy 14(4):576-601.

Broome, André, and Leonard Seabrooke. 2015. "Shaping Policy Curves: Cognitive Authority in Transnational Capacity Building." Public Administration 93(4):956-72.

Broome, André, Alexandra Homolar, and Matthias Kranke. 2017. "Bad Science: International Organizations and the Indirect Power of Global Benchmarking." European Journal of International Relations. Online first.

Chabot, Sean, and Jan Willem Duyvendak. 2002. "Globalization and Transnational Diffusion between Social Movements: Reconceptualizing the Dissemination of the Gandhian Repertoire and the 'Coming Out' Routine." Theory and Society 31(6):697-740.

Chang, Ha-Joon. 2006. "Policy Space in Historical Perspective with Special Reference to Trade and Industrial Policies." Economic and Political Weekly 41(7):627-33.

Chase-Dunn, Christopher K. 1998. Global Formation: Structures of the WorldEconomy. Lanham, MD: Rowman \& Littlefield.

Chinn, Menzie D., and Hiro Ito. 2008. "A New Measure of Financial Openness." Journal of Comparative Policy Analysis 10(3):309-322.

Chorev, Nitsan. 2012a. "Changing Global Norms through Reactive Diffusion: The Case of Intellectual Property Protection of AIDS Drugs." American Sociological Review 77(5):831-53.

Chorev, Nitsan. 2012b. The World Health Organization between North and South. Ithaca, NY: Cornell University Press.

Chorev, Nitsan. 2012c. "A New Health Order as Part of the New Social Order': 
The Strategic Response of the WHO to Its Member States." Pp. 65-100 in Political Power and Social Theory, Vol. 23, edited by J. Go. Bingley, UK: Emerald Group Publishing.

Chorev, Nitsan. 2013. "Restructuring Neoliberalism at the World Health Organization." Review of International Political Economy 20(4):627-66.

Chorev, Nitsan, and Sarah Babb. 2009. "The Crisis of Neoliberalism and the Future of International Institutions: A Comparison of the IMF and the WTO." Theory and Society 38(5):459-84.

Chwieroth, Jeffrey M. 2010. Capital Ideas: The IMF and the Rise of Financial Liberalization. Princeton, NJ: Princeton University Press.

Clinton, Chelsea, and Devi Sridhar. 2017. Governing Global Health: Who Runs the World and Why? Oxford: Oxford University Press.

Coupé, Tom. 2003. "Revealed Performances: Worldwide Rankings of Economists and Economics Departments, 1990-2000." Journal of the European Economic Association 1(6):1309-45.

Dezalay, Yves, and Bryant. G. Garth. 2002. The Internationalization of Palace Wars: Lawyers, Economists, and the Contest to Transform Latin American States. Chicago: University of Chicago Press.

Dobbin, Frank, Beth Simmons, and Geoffrey Garrett. 2007. "The Global Diffusion of Public Policies: Social Construction, Coercion, Competition, or Learning?" Annual Review of Sociology 33(1):449-72.

Dooley, Michael P. 1988. "Capital Flight: A Response to Differences in Financial Risks." Staff Papers - International Monetary Fund 35(3):422-36.

Dooley, Michael P., Jeffrey Frankel, and Donald J. Mathieson. 1988. "International Capital Mobility: What Do Saving-Investment Correlations Tell Us? Reply to Miller." Staff Papers - International Monetary Fund 35(2):397-98.

Drori, Gili S., and John W. Meyer. 2006a. "Global Scientization: An Environment for Expanded Organization." Pp. 50-68 in Globalization and Organization: World Society and Organizational Change, edited by G. S. Drori, J. 
W. Meyer, and H. Hwang. Oxford: Oxford University Press.

Drori, Gili S., and John W. Meyer. 2006b. "Scientization: Making a World Safe for Organizing." Pp. 31-52 in Transnational Governance: Institutional Dynamics of Regulation, edited by M.-L. Djelic and K. Sahlin-Andersson. Cambridge, UK: Cambridge University Press.

Drori, Gili S., John W. Meyer, and Hokyu Hwang, eds. 2006. Globalization and Organization: World Society and Organizational Change. Oxford: Oxford University Press.

Ebrill, Liam, Jean-Paul Bodin, Michael Keen, and Victoria Summers, eds. 2001. The Modern VAT. Washington, DC: International Monetary Fund.

Fischer, Stanley. 1997. "Seminar - Asia and the IMF." International Monetary $\begin{array}{llll}\text { Fund. } & \text { Retrieved } & \text { March } & 12,\end{array}$ (https://www.imf.org/external/np/speeches/1997/091997.htm).

Fischer, Stanley. 1998. "Capital-Account Liberalization and the Role of the IMF." Pp. 1-10 in Should the IMF Pursue Capital-Account Convertibility? edited by S. Fischer, R. N. Cooper, R. Dornbusch, P. M. Garber, C. Massad, J. J. Polak, D. Rodrik, and S. S. Tarapore. Princeton, NJ: Princeton Essays in International Finance.

Fjeldstad, Odd-Helge, and Mick Moore. 2008. "Tax Reform and State Building in a Globalized World." Pp. 235-60 in Taxation and State Building in Developing Countries, edited by D. Brautigam, O.-H. Fjeldstad, and M. Moore. Cambridge, UK: Cambridge University Press.

Frank, David John, Bayliss J. Camp, and Steven A. Boutcher. 2010. "Worldwide Trends in the Criminal Regulation of Sex, 1945 to 2005." American Sociological Review 75(6):867-93.

Frenkel, Jacob A., and Assaf Razin. 1988. "International Effects of Tax Reforms." IMF Working Paper (WP/88/62).

Gehlbach, Scott. 2008. Representation through Taxation: Revenue, Politics, and Development in Postcommunist States. Cambridge, UK: Cambridge University Press. 
Gilson, Lucy, and Di McIntyre. 2005. "Removing User Fees for Primary Care in Africa: The Need for Careful Action." BMJ 331(7519):762-65.

Grabel, Ilene. 2011. "Not Your Grandfather's IMF: Global Crisis, 'Productive Incoherence' and Developmental Policy Space." Cambridge Journal of Economics $35(5): 805-830$.

Green, Jessica F. 2014. Rethinking Private Authority: Agents and Entrepreneurs in Global Environmental Governance. Princeton, NJ: Princeton University Press.

Gros, Daniel. 1987. "The Effectiveness of Capital Controls: Implications for Monetary Autonomy in the Presence of Incomplete Market Separation." Staff Papers - International Monetary Fund 34(4):621-42.

Halliday, Terence C. 2009. "Recursivity of Global Normmaking: A Sociolegal Agenda." Annual Review of Law and Social Science 5(1):263-89.

Halliday, Terence C., and Bruce G. Carruthers. 2007. "The Recursivity of Law: Global Norm Making and National Lawmaking in the Globalization of Corporate Insolvency Regimes." American Journal of Sociology 112(4):1135-1202.

Halliday, Terence C., and Bruce G. Carruthers. 2009. Bankrupt: Global Lawmaking and Systemic Financial Crisis. Stanford, CA: Stanford University Press.

Halliday, Terence C., Susan Block-Lieb, and Bruce G. Carruthers. 2010. "Rhetorical Legitimation: Global Scripts as Strategic Devices of International Organizations." Socio-Economic Review 8(1):77-112.

Halliday, Terence C., Josh Pacewicz, and Susan Block-Lieb. 2013. "Who Governs? Delegations and Delegates in Global Trade Lawmaking." Regulation \& Governance 7(3):279-98.

Helleiner, Eric. 2014. Forgotten Foundations of Bretton Woods: International Development and the Making of the Postwar Order. Ithaca, NY: Cornell University Press.

Henriksen, Lasse F., and Leonard Seabrooke. 2016. "Transnational Organizing: 
Issue Professionals in Environmental Sustainability Networks." Organization 23(5):722-41.

Hironaka, Ann. 2014. Greening the Globe: World Society and Environmental Change. Cambridge, UK: Cambridge University Press.

Hopgood, Stephen. 2006. Keepers of the Flame: Understanding Amnesty International. Ithaca, NY: Cornell University Press.

International Monetary Fund (IMF). 1981. Annual Report of the Executive Board. Washington, DC: International Monetary Fund.

International Monetary Fund (IMF). 1984. Review of Experience with Multiple Exchange Rate Regimes. Staff Memorandum/84/64. IMF Archives.

International Monetary Fund (IMF). 1985. Multiple Currency Practices Applicable Solely to Capital Transactions. Staff Memorandum/85/19. IMF Archives.

International Monetary Fund (IMF). 1990a. Capital Flows - Determinants and Systemic Consequences. Executive Board Minutes/90/121 (July 25). IMF Archives.

International Monetary Fund (IMF). 1990b. The Determinants and Systemic Consequences of International Capital Flows. Staff Memorandum/90/128. IMF Archives.

International Monetary Fund (IMF). 1991. Annual Report of the Executive Board. Washington, DC: International Monetary Fund.

International Monetary Fund (IMF). 1992a. Tanzania-1992 Article IV Consultation; and Enhanced Structural Adjustment Facility-Second Annual Arrangement. Executive Board Minutes/92/141 (November 25). IMF Archives.

International Monetary Fund (IMF). 1992b. Tanzania-Enhanced Structural Adjustment Facility-Review Under First Annual Arrangement; and Exchange System. Executive Board Minutes/92/61 (May 4). IMF Archives.

International Monetary Fund (IMF). 1992c. Tanzania-Staff Report for the 1992 
Article IV Consultation, and Request for the Second Annual Arrangement Under the Enhanced Structural Adjustment Facility. Executive Board Special/92/170. IMF Archives.

International Monetary Fund (IMF). 1995a. A Survey of Academic Literature on Controls Over International Capital Transactions. Staff Memorandum/95/164, Supplement 3. IMF Archives.

International Monetary Fund (IMF). 1995b. Capital Account ConvertibilityReview of Experience and Implications for Fund Policies. Staff Memorandum/95/164. IMF Archives.

International Monetary Fund (IMF). 1995c. Capital Account ConvertibilityReview of Experience, and Implications for Fund Policy. Executive Board Minutes/95/73 (July 28). IMF Archives.

International Monetary Fund (IMF). 1996a. Tanzania-1996 Article IV Consultation; and Enhanced Structural Adjustment Arrangement. Executive Board Minutes/96/101 (November 8). IMF Archives.

International Monetary Fund (IMF). 1996b. Tanzania-Staff Report for the 1996 Article IV Consultation and Request for a Three-Year Arrangement Under the Enhanced Structural Adjustment Facility. Executive Board Special/96/165. IMF Archives.

International Monetary Fund (IMF). 1997a. Capital Account Convertibility and a Possible Amendment of the Articles-Further Considerations. Staff Memorandum/97/86. IMF Archives.

International Monetary Fund (IMF). 1997b. Capital Account Convertibility and the Role of the Fund-Review of Experience and Consideration of a Possible Amendment of the Articles. Staff Memorandum/97/32. IMF Archives.

International Monetary Fund (IMF). 1997c. Capital Account ConvertibilityConsideration of Possible Amendment of Articles of Agreement-Further Considerations. Executive Board Minutes/97/38 (April 15). IMF Archives.

International Monetary Fund (IMF). 1997d. Capital Movements Under an Amendment of the Articles of Agreement-Draft Report of Executive Board to 
Interim Committee. Executive Board Minutes/97/93 (September 8). IMF Archives.

International Monetary Fund (IMF). 1997e. Draft Report to the Interim Committee on the Liberalization of Capital Movements Under an Amendment of the Articles. Staff Memorandum/97/230. IMF Archives.

International Monetary Fund (IMF). 1997f. World Economic Outlook, Interim Assessment-Crisis in Asia: Regional and Global Implications. Retrieved March 12, 2016 (http://www.imf.org/external/pubs/ft/weo/weo1297/).

International Monetary Fund (IMF). 1997g. Legal Aspects of Capital Movements Under an Amendment of the Articles-Further Considerations. Staff Memorandum/97/209. IMF Archives.

International Monetary Fund (IMF). 1997h. Review of Experience with Capital Account Liberalization and Strengthened Procedures Adopted by the Fund. Staff Memorandum/97/32, Supplement 1. IMF Archives.

International Monetary Fund (IMF). 1998a. Capital Account LiberalizationTheoretical and Practical Aspects. Executive Board Minutes/98/85 (August 3). IMF Archives.

International Monetary Fund (IMF). 1998b. Liberalization of Capital Movements Under an Amendment of Articles-Statement by Managing Director. Executive Board Minutes/98/38 (April 2). IMF Archives.

International Monetary Fund (IMF). 1999. Use of Controls on Capital Movements and Issues in Their Orderly Liberalization-Countries' Experiences. Executive Board Minutes/99/31 (March 24). IMF Archives.

International Monetary Fund (IMF). 2000a. Tanzania-Request for a Three-Year Arrangement Under the Poverty Reduction and Growth Facility. Executive Board Special/00/44. IMF Archives.

International Monetary Fund (IMF). 2000b. Tanzania-Staff Report for the 2000 Article IV Consultation and First Review Under the Poverty Reduction and Growth Facility. Executive Board Special/00/147. IMF Archives. 
International Monetary Fund (IMF). 2001a. Annual Report of the Executive Board. Washington, DC: International Monetary Fund.

International Monetary Fund (IMF). 2001b. Tanzania-Staff Report for the 2001 Article IV Consultation and Third Review Under the Three-Year Arrangement Under the Poverty Reduction and Growth Facility. Executive Board Special/01/153. IMF Archives.

International Monetary Fund (IMF). 2002. Tanzania-Poverty Reduction and Growth Facility - Three-Year Arrangement - Review, and Waiver of Performance Criterion. Executive Board Minutes/02/41 (April 15). IMF Archives.

International Monetary Fund (IMF). 2006. United Republic of Tanzania-Fifth Review Under the Three-Year Arrangement Under the Poverty Reduction and Growth Facility. Executive Board Special/06/41. IMF Archives.

International Monetary Fund (IMF). 2011. Articles of Agreement of the International Monetary Fund. Washington, DC: International Monetary Fund.

Joshi, Anuradha, and Joseph Ayee. 2008. "Associational Taxation: A Pathway into the Informal Sector?" Pp. 183-211 in Taxation and State-Building in Developing Countries, edited by D. Brautigam, O.-H. Fjeldstad, and M. Moore. Cambridge, UK: Cambridge University Press.

Jupille, Joseph, Walter Mattli, and Duncan Snidal. 2013. Institutional Choice and Global Commerce. Cambridge, UK: Cambridge University Press.

Keen, Michael. 2000. "VIVAT, CVAT and All That: New Forms of Value-Added Tax for Federal Systems." IMF Working Paper (WP/00/83).

Keen, Michael, and Ben Lockwood. 2010. "The Value Added Tax: Its Causes and Consequences." Journal of Development Economics 92(2):138-51.

Kennedy, David. 1986. "International Refugee Protection." Human Rights Quarterly 8(1):1-69.

Kentikelenis, Alexander E. 2017a. "Structural Adjustment and Health: a Conceptual Framework and Evidence on Pathways." Social Science 65 Medicine 187:296-305. 
Kentikelenis, Alexander E. 2017b. "The Social Aftermath of Economic Disaster: Karl Polanyi, Countermovements in Action, and the Greek Crisis." SocioEconomic Review. Online first.

Kentikelenis, Alexander E., Thomas H. Stubbs, and Lawrence P. King. 2016. "IMF Conditionality and Development Policy Space, 1985-2014." Review of International Political Economy 23(4):543-82.

Keynes, John M. 1943. "Proposals for an International Clearing Union." International Monetary Fund. Retrieved March 13, 2016 (http://imsreform.imf.org/reserve/pdf/keynesplan.pdf).

Kim, Hun Joon, and Jason C. Sharman. 2014. "Accounts and Accountability: Corruption, Human Rights, and Individual Accountability Norms." International Organization 68(2):417-48.

King, Lawrence P., and Aleksandra Sznajder. 2006. "The State-Led Transition to Liberal Capitalism: Neoliberal, Organizational, World-Systems, and Social Structural Explanations of Poland's Economic Success." American Journal of Sociology 112(3):751-801.

Koremenos, Barbara, Charles Lipson, and Duncan Snidal. 2001. "The Rational Design of International Institutions." International Organization 55(4):761-99.

Levitt, Peggy, and Sally Merry. 2009. "Vernacularization on the Ground: Local Uses of Global Women's Rights in Peru, China, India and the United States." Global Networks 9(4):441-61.

Li, Xue, and Alexander Hicks. 2016. "World Polity Matters: Another Look at the Rise of the Nation-State Across the World, 1816 to 2001." American Sociological Review 81(3):596-607.

Marcussen, Martin, and Jarle Trondal. 2011. "The OECD Civil Servant: Caught between Scylla and Charybdis." Review of International Political Economy 18(5):592-621.

Martinez-Diaz, Leonardo. 2009. "Boards of Directors in International Organizations: A Framework for Understanding the Dilemmas of Institutional 
Design." Review of International Organizations 4(4):383-406.

Mattli, Walter, and Jack Seddon. 2015. "New Organizational Leadership: Nonstate Actors in Global Economic Governance." Global Policy 6(3):266-76.

Meyer, John W. 2000. "Globalization: Sources and Effects on National States and Societies." International Sociology 15(2):233-48.

Meyer, John W., John Boli, George M. Thomas, and Francisco O. Ramirez. 1997. "World Society and the Nation-State." American Journal of Sociology 103(1):14481.

Meyer, John W., Gili S. Drori, and Hokyu Hwang. 2006. "World Society and the Proliferation of Formal Organization." Pp. 25-49 in Globalization and Organization: World Society and Organizational Change, edited by G. S. Drori, J. W. Meyer, and H. Hwang. Oxford: Oxford University Press.

Meyer, John W., David John Frank, Ann Hironaka, Evan Schofer, and Nancy Brandon Tuma. 1997. "The Structuring of a World Environmental Regime, 18701990." International Organization 51(4):623-51.

Mills, C. Wright. 1956. The Power Elite. Oxford: Oxford University Press.

Mizruchi, Mark S. 1996. "What Do Interlocks Do? An Analysis, Critique, and Assessment of Research on Interlocking Directorates." Annual Review of Sociology 22:271-98.

Nelson, Stephen C. 2014. "Playing Favorites: How Shared Beliefs Shape the IMF's Lending Decisions." International Organization 68(2):297-328.

Overdevest, Christine and Jonathan Zeitlin. 2012. "Assembling an Experimentalist Regime: Transnational Governance Interactions in the Forest Sector." Regulation \& Governance 8(1):22-48.

Pauly, Louis W. 1997. Who Elected the Bankers? Surveillance and Control in the World Economy. Ithaca, NY: Cornell University Press.

Portugal, Murilo. 2005. "Improving IMF Governance and Increasing the Influence of Developing Countries in IMF Decision-Making." Pp. 75-106 in Reforming the 
Governance of the IMF and the World Bank, edited by A. Buira. London: Anthem Press.

Quinn, Dennis P., and A. Maria Toyoda. 2008. "Global Ideology and Voter Sentiment as Determinants of International Financial Liberalization." Pp. 173219 in The Global Diffusion of Markets and Democracy, edited by J. Simmons, F. Dobbin, and G. Garrett. Cambridge, UK: Cambridge University Press.

Radelet, Steven, and Jeffrey D. Sachs. 1998. "The East Asian Financial Crisis: Diagnosis, Remedies, Prospects." Brookings Papers on Economic Activity 1998(1):1-90.

Rodrik, Dani. 1998. "Who Needs Capital-Account Convertibility?" Pp. 55-65 in Should the IMF Pursue Capital-Account Convertibility? edited by S. Fischer, R. N. Cooper, R. Dornbusch, P. M. Garber, C. Massad, J. J. Polak, D. Rodrik, and S. S. Tarapore. Princeton, NJ: Princeton Essays in International Finance.

Schmidt, Vivien A. 2016. "Reinterpreting the Rules 'by Stealth' in Times of Crisis: A Discursive Institutionalist Analysis of the European Central Bank and the European Commission." West European Politics 39(5):1032-52.

Schofer, Evan. 2003. "The Global Institutionalization of Geological Science, 1800 to 1990." American Sociological Review 68(5):730-59.

Schofer, Evan. 2004. "Cross-National Differences in the Expansion of Science, 1970-1990." Social Forces 83(1):215-48.

Schofer, Evan, Ann Hironaka, David John Frank, and Wesley Longhofer. 2012. "Sociological Institutionalism and World Society." Pp. 57-68 in The WileyBlackwell Companion to Political Sociology, edited by E. Amenta, K. Nash, and A. Scott. Oxford, UK: Wiley-Blackwell.

Seabrooke, Leonard and Lasse F. Henriksen, eds. 2017. Professional Networks in Transnational Governance. Cambridge: Cambridge University Press.

Seabrooke, Leonard, and Duncan Wigan. 2016. "Powering Ideas Through Expertise: Professionals in Global Tax Battles." Journal of European Public Policy 23(3):357-74. 
Sharman, Jason C. 2012. "Seeing Like the OECD on Tax." New Political Economy 17(1):17-33.

Shome, Parthasarathi. 1995. Tax Policy Handbook. Washington, DC: International Monetary Fund.

Shwed, Uri, and Peter S. Bearman. 2010. "The Temporal Structure of Scientific Consensus Formation." American Sociological Review 75(6):817-40.

Steinberg, Richard H. 2002. "In the Shadow of Law or Power? Consensus-Based Bargaining and Outcomes in the GATT/WTO." International Organization 56(2):339-74.

Stiglitz, Joseph E. 2000. "Capital Market Liberalization, Economic Growth, and Instability." World Development 28(6):1075-86.

Stiglitz, Joseph E. 2010. "Development-Oriented Tax Policy." Pp. 11-36 in Taxation in Developing Countries: Six Case Studies and Policy Implications, edited by R. Gordon. New York: Columbia University Press.

Stroup, Sarah S., and Wendy H. Wong. 2017. The Authority Trap: Strategic Choices of International NGOs. Ithaca, NY: Cornell University Press.

Tait, Alan A. 1988. Value Added Tax: International Practice and Problems. Washington, DC: International Monetary Fund.

Tanzi, Vito. 1992. Fiscal Policies in Economies in Transition. Washington, DC: International Monetary Fund.

Tanzi, Vito. 1994. "The IMF and Tax Reform." Pp. 445-68 in Tax Policy and Planning in Developing Countries, edited by A. Bagchi and N. H. Stern. New York: Oxford University Press.

Tsingou, Eleni. 2015. "Club Governance and the Making of Global Financial Rules." Review of International Political Economy 22(2):225-56.

Vreeland, James R. 2007. The International Monetary Fund: Politics of Conditional Lending. Abingdon, UK: Routledge. 
Wade, Robert H. 1996. "Japan, the World Bank, and the Art of Paradigm Maintenance: The East Asian Miracle in Political Perspective." New Left Review $\mathrm{I} / 217: 3-36$.

Wade, Robert H. 2001. "Capital and Revenge: The IMF and Ethiopia." Challenge 44(5):67-75.

Wade, Robert H. 2011. "Emerging World Order? From Multipolarity to Multilateralism in the G20, the World Bank, and the IMF." Politics 85 Society 39(3):347-78.

Wade, Robert H., and Frank Veneroso. 1998a. "The Gathering World Slump and the Battle Over Capital Controls." New Left Review I/231:13-42.

Wade, Robert H., and Frank Veneroso. 1998b. "The Asian Crisis: The High Debt Model versus the Wall Street-Treasury-IMF Complex." New Left Review I/288:324 .

Walder, Andrew, Andrew Isaacson, and Qinglian Lu. 2015. "After State Socialism." American Sociological Review 80(2):444-68.

Walton, John, and Charles C. Ragin. 1990. "Global and National Sources of Political Protest: Third World Responses to the Debt Crisis." American Sociological Review 55(6):876-90.

Wedel, Janine R. 2001. Collision and Collusion: The Strange Case of Western Aid to Eastern Europe. New York: Palgrave Macmillan.

Wimmer, Andreas, and Yuval Feinstein. 2010. "The Rise of the Nation-State Across the World, 1816 to 2001." American Sociological Review 75(5):764-90.

Wimmer, Andreas, and Yuval Feinstein. 2016. "Still No Robust Evidence for World Polity Theory." American Sociological Review 81(3):608-615.

Woods, Ngaire. 2006. The Globalizers: The IMF, the World Bank, and Their Borrowers. Ithaca, NY: Cornell University Press.

World Bank. 2015. "Speech by World Bank Group President Jim Yong Kim." $\begin{array}{lll}\text { Retrieved } & \text { March } & 22,\end{array}$ 
(http://www.worldbank.org/en/news/speech/2015/10/01/speech-world-bankgroup-president-shared-prosperity-equal-opportunity).

Zee, Howard H. 2000. "Retarding Short-Term Capital Inflows Through Withholding Tax." IMF Working Paper (WP/00/40).

Zeitlin, Jonathan, ed. 2015. Extending Experimentalist Governance? The European Union and Transnational Regulation. Oxford: Oxford University Press.

\section{BIOGRAPHIES}

Alexander Kentikelenis is a research fellow in sociology and politics at the University of Oxford (Trinity College), and assistant professor of sociology and political economy at the University of Amsterdam. He has published extensively on global governance issues, and on the social and political consequences of economic policy reforms and austerity. His book, Austerity without a Safety Net, is forthcoming from Oxford University Press.

Leonard Seabrooke is professor of international political economy and economic sociology at the Copenhagen Business School. He has published extensively on networks of influence in economic policy design, especially on taxation, finance, housing, and demographic change issues. His recent books include a co-authored monograph, Global Tax Battles (2018), with Oxford University Press, and the edited volumes Professional Networks in Transnational Governance (2017) with Cambridge University Press, and Global Wealth Chains (2018) with Oxford University Press. 
Table 1. Script-writing in Intergovernmental Organizations

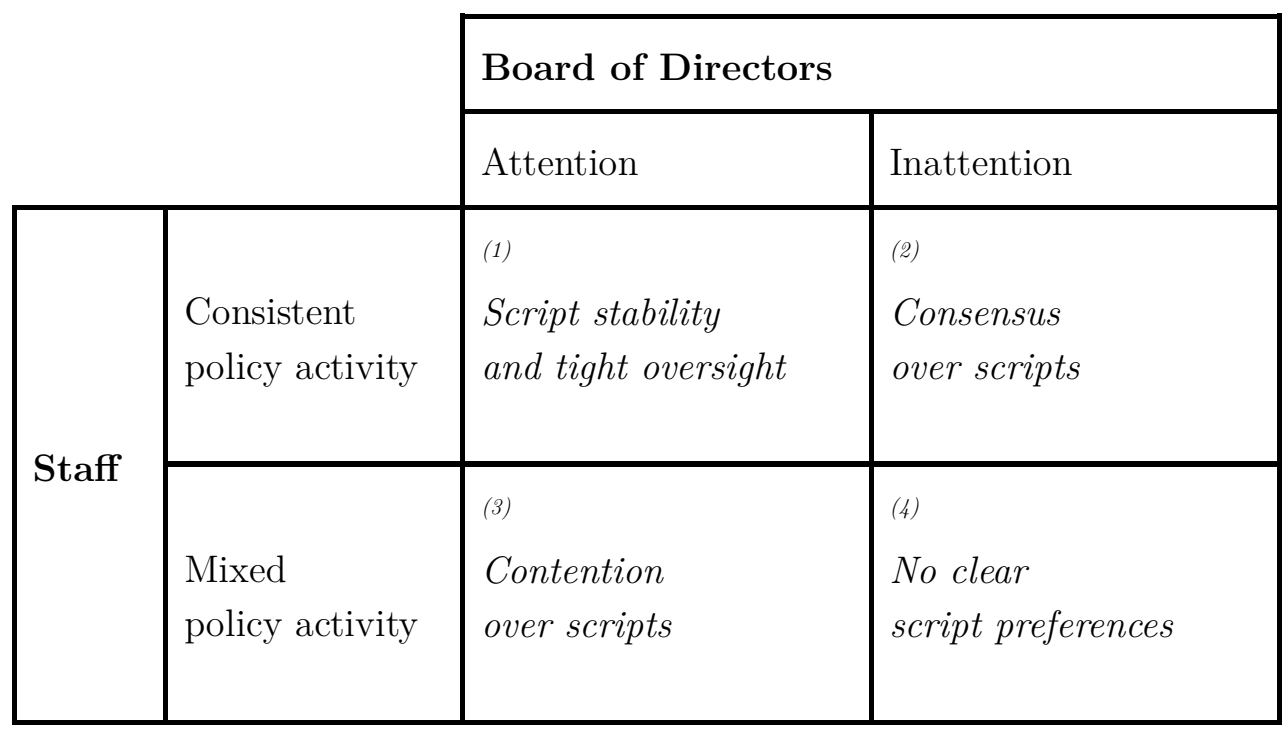


Table 2. Education Characteristics of Senior IMF Appointees, 1980 to 2000

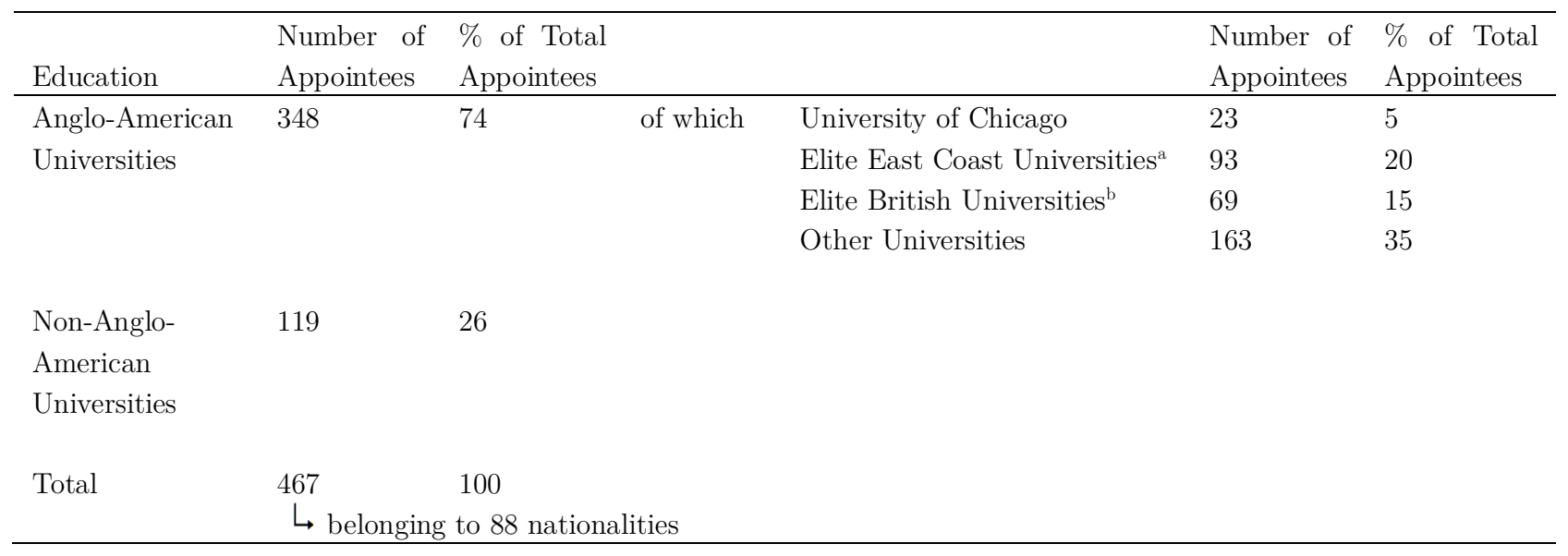

Note: Table created using data provided by Nelson (2014). The criterion for classifying seniority was the appointee holding the rank of division chief or higher.

aWe identified six U.S. East Coast universities as elite based on their economics departments' ranking (Coupé 2003): MIT, Harvard, Yale, Columbia, Pennsylvania, and Princeton.

${ }^{b}$ We classified Oxford, Cambridge, and the London School of Economics as elite British universities. 
Figure 1. Power Structures in Intergovernmental Organizations

\begin{tabular}{|c|c|c|c|c|c|c|}
\hline \multirow{2}{*}{$\begin{array}{l}\text { Low-income } \\
\text { countries }\end{array}$} & \multirow{2}{*}{$\begin{array}{l}\text { Middle-income } \\
\text { countries }\end{array}$} & \multicolumn{3}{|c|}{ Managing } & \multirow{2}{*}{$\begin{array}{l}\text { Policy } \\
\text { Staff }\end{array}$} & \multirow{2}{*}{$\begin{array}{r}\text { Young } \\
\text { Professionals }\end{array}$} \\
\hline & & $\begin{array}{l}\text { ngnties } \\
\text { countries }\end{array}$ & USA & Management & & \\
\hline
\end{tabular}


Figure 2. The Spread of VAT

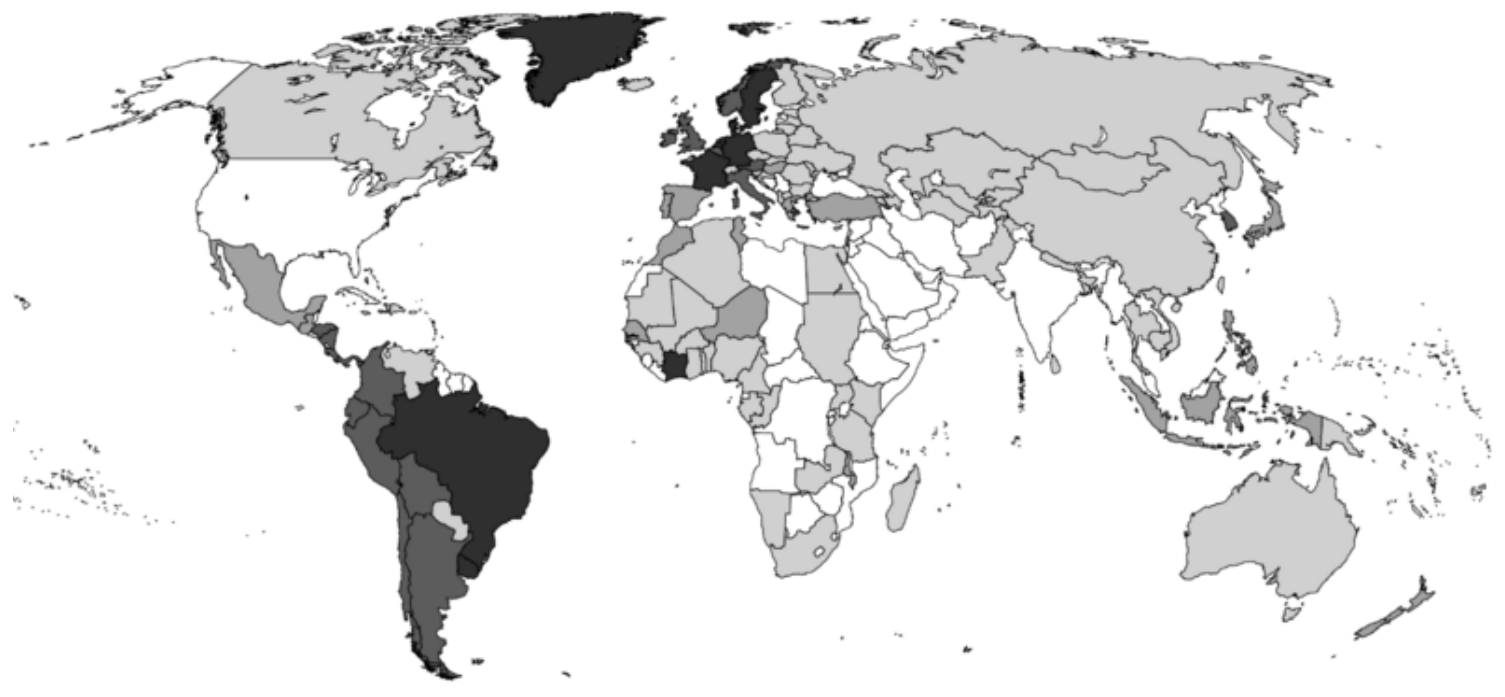

Source: Ebrill et al. 2001:xiv-xv. 
Figure 3. Policy Scripts in Practice: Introducing VAT

\begin{tabular}{|c|c|c|c|}
\hline $\begin{array}{l}\text { Chronological Schedule of Work } \\
\text { to Be Done to Introduce a VAT } \\
\text { in About Eighteen Months } \\
\text { The following timetable sets out broad guidelines for the work that } \\
\text { needs to be done month by month starting July } 1988 \text { to introduce a } \\
\text { var by, say, January 1, 1990, and enforce it effectively thereafter. It } \\
\text { might be intended as an aide-mémoire for the head of the vAT } \\
\text { committee and for the heads of the various subcommittees preparing } \\
\text { the vaT. Progress should be monitored regularly to identify any } \\
\text { failure that could jeopardize the planning or the proper implementa- } \\
\text { tion of the vAT on the target date. It has to be pointed out that while } \\
\text { the list may appear reasonably comprehensive, there will inevitably } \\
\text { still be many unrecorded auxiliary activities to which attention has to } \\
\text { be given if the vAT is to be implemented successfully and on time. } \\
\text { Month } \\
\text { By end-1988 Tasks } \\
\text { 1. Settle policy proposals on the scope and the } \\
\text { structure of the vAT, including a cost-benefit } \\
\text { analysis, and on transitional measures, and } \\
\text { obtain the relevant ministerial approval with } \\
\text { regard to policy, the funding plan, and so on. } \\
\text { 2. Training subcommittee prepares training } \\
\text { plan, identifies training courses and orienta- } \\
\text { tion seminars for executives and managers, } \\
\text { selects training staff, and identifies the need } \\
\text { for other training resources, such as office } \\
\text { space, photocopiers, and secretarial support. } \\
\text { 3. Design and present an orientation seminar on } \\
\text { the basic principles of vaT for executives and } \\
\text { managers at the revenue, customs, and excise } \\
\text { departments. }\end{array}$ & $\begin{array}{l}\text { 4. Prepare a course for training all supervisors } \\
\text { and operating personnel concerned with the } \\
\text { VAT in the revenue and customs departments } \\
\text { on the basic principles of VAT operation. } \\
\text { 5. Design VAT return form, vAT payment form, } \\
\text { and application form for VAT registration. } \\
\text { 6. Within the revenue department, determine } \\
\text { the administrative framework of the VAT, } \\
\text { such as detailed procedures for the registra- } \\
\text { tion of taxpayers, processing of VAT returns, } \\
\text { audit for VAT, and collection procedures. } \\
\text { 7. Start discussion on the extent of computer } \\
\text { support in VAT administration and the sys- } \\
\text { tem's design. } \\
\text { 8. Identify the resource needs for implementa- } \\
\text { tion of the vAT, with particular attention to } \\
\text { funding and the filling of outstanding vacan- } \\
\text { cies. } \\
\text { 9. Legal subcommittee starts discussion on VAT } \\
\text { and drafts laws and basic regulations. } \\
\text { 10. Make final decisions, both within the revenue } \\
\text { department and with the customs depart- } \\
\text { ment, on registration procedures and the in- } \\
\text { corporation of vAT registration information } \\
\text { in the tax master file. } \\
\text { 11. Discuss with the customs department the role } \\
\text { of customs in the enforcement of the VAT. } \\
\text { 12. Decide on computer involvement and conse- } \\
\text { quently determine the needs for changes in } \\
\text { existing programs and/or the development of } \\
\text { new programs. } \\
\text { 13. Determine the broad setup of the administra- } \\
\text { tive system for vAT and examine possible } \\
\text { consequences for the organization of the rev- } \\
\text { enue department. } \\
\text { 14. Draft a simple vAT information booklet for } \\
\text { press and public use, for distribution in Feb- } \\
\text { ruary } 1989 \text {. } \\
\text { 15. Produce a trial list of potential vAT taxpayers } \\
\text { based on the information available in: }\end{array}$ & January 1989 & $\begin{array}{l}\text { - The revenue department's computer sys- } \\
\text { tem (data on business tax and income } \\
\text { tax). } \\
\text { - The customs department (exporters and } \\
\text { importers). } \\
\text { - Local manual listings, knowledge and } \\
\text { surveys, including press advertisements } \\
\text { and telephone directories. } \\
\text { 16. Make a preliminary estimate of staff required } \\
\text { in each office to administer the vAT at the } \\
\text { beginning of each month as registration, edu- } \\
\text { cational visits, collection, enforcement, and } \\
\text { verification progress. The estimate should be } \\
\text { based on the numbers of likely taxpayers on } \\
\text { the list at } 15 \text { above. } \\
\text { 17. Begin preparation of a staff manual on the } \\
\text { vaT legislation and procedures. } \\
\text { 18. Draft staff manual on VAT registration proce- } \\
\text { dures. } \\
\text { 19. Start preparations for extensive publicity } \\
\text { campaign to be held from May } 1989 \text {, includ- } \\
\text { ing the production of publicity literature. } \\
\text { 1. Review all actions to date and monitor prog- } \\
\text { ress to identify delays. } \\
\text { 2. Complete preliminary draft of the vaT law } \\
\text { for full committee review. } \\
\text { 3. Give course on vAT principles to relevant su- } \\
\text { pervisors and operating personnel. } \\
\text { 4. Design forms for vAT administration. } \\
\text { 5. Design general audit policy for vAT. } \\
\text { 6. Work out curriculum for VAT auditors' train- } \\
\text { ing, determine content of manuals for that } \\
\text { training, and select instructors. } \\
\text { 7. Establish vaT units in each regional, provin- } \\
\text { cial, district, and area offices. } \\
\text { 1. Complete drafting of vat law and submit } \\
\text { draft for government approval. } \\
\text { 2. Conduct first media campaign to inform the }\end{array}$ \\
\hline
\end{tabular}

Source: Tait 1988:409-416.

...continued (not presented here) 
Figure 4. The Spread of Capital Openness

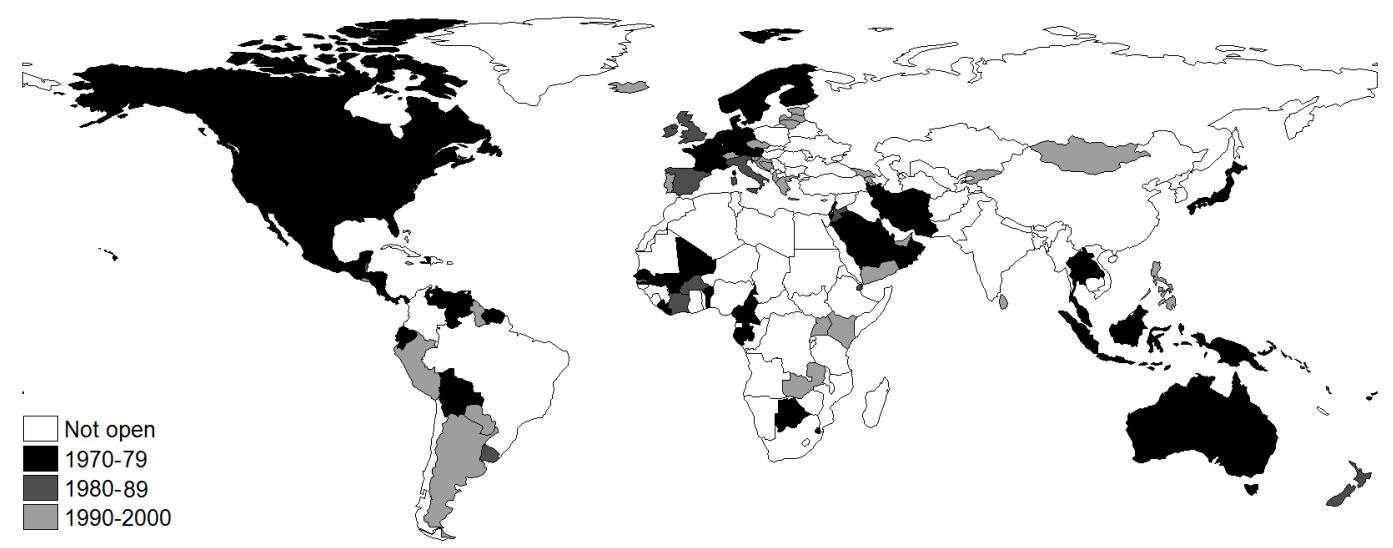

Source: Based on data from Chinn and Ito (2008).

Note: The Chinn-Ito index measures the degree of countries' reliance on capital controls, drawing on information provided in the IMF's Annual Report on Exchange Arrangements and Exchange Restrictions. A 0 denotes a closed capital account (e.g., Iran throughout the 1990s), and a 1 denotes complete capital account openness (e.g., the United States throughout this period). We define the onset of capital openness as the decade in which a country scored .33 or above, on average. 
Figure 5. Loci of Politics and Science in Intergovernmental Organizations

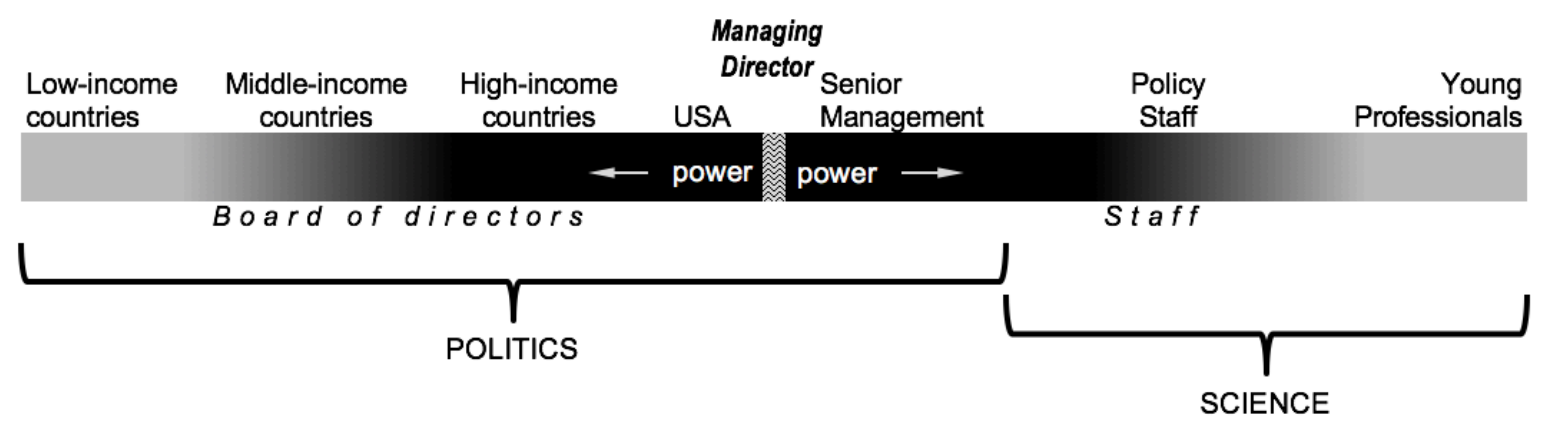

